\title{
GEOELECTRICAL ANALYSIS ON THE GROUNDWATER OCCURRENCE FOR THE DEVELOPMENT OF EAST EL MINYA GOVERNORATE, EGYPT
}

\section{THARWAT H. ABDEL HAFEEZ ${ }^{1}$, HASSAN S. SABET ${ }^{1}$, AHMED N. EL SAYED ${ }^{2}$}

\section{AND MAHMOUD A. ZAYED ${ }^{1}$}

Departments of ${ }^{1}$ Geology, Faculty of Science, Al-Azhar University and ${ }^{2}$ Geophysics, Desert Research Center, Cairo, Egypt.

\begin{abstract}
The investigated area is a part of Nile valley which is surrounded by limestone plateaus of Egypt. It is located between Latitudes $28^{\circ} 15^{\prime}-28^{\circ} 45^{\prime} N$ and Longitudes $30^{\circ} 45-31^{\circ} 00^{\prime} \mathrm{E}$, and has a surface area of about 1362 Square kilometers. The geoelectrical resistivity measurements have been carried out, using a Schlumberger array to identify the resistivity and thicknesses of different subsurface layers and determine groundwater occurrences. For these purpose, 44 Schlumberger vertical electrical soundings (VES) were conducted with a maximum half current electrode spacing of $700 \mathrm{~m}$. Results from the quantitative interpretation of sounding data indicate that, the area is generally underlain by five main geoelectrical units $(A, B, C$, $D$ and $E$ ). The main characteristics of these geoelectrical layers as well as, the main features of the constructed geoelectrical cross sections have been interpreted in the case of determining the groundwater occurrences. Based on the results obtained, four water-bearing layers (aquifers) were detected in the investigated area. The Quaternary deposits represented by Pleistocene Neonile Sediments of sands and gravels with clay and Shale lenses (A3) act as the first aquifer which represents a limited distribution in the investigated area. The second water-bearing layer (C1) corresponds to water-bearing limestone of Maghagha Formation which lead to the second aquifer and represents also a limited distribution in the investigated area. The third one (D4) corresponds to water-bearing limestone of Samalut Formation which lead to the third aquifer and represents a wide distribution in the investigated area. The fourth water bearing zone (E) corresponds to water-bearing limestone of Minia Formation which lead to the fourth aquifer and represents a wide distribution in the investigated area. Two priority maps for groundwater exploitation in the investigated area have been presented for each of El Minia and Samalut aquifers. It can be concluded that, the priority is generally increasing toward the southern parts, especially at wadi El Saririia area, where El Minia Aquifer occupy the first category and at wadi El Sheikh Hasan where the two main aquifers of Samalut and El Minia facies are well represented.

Keywords: Schlumberger, Vertical Electrical Sounding (VES), Water-Bearing Limestone, Geoelectric and Groundwater Occurrences.
\end{abstract}

\section{INTRODUCTION}

The Nile valley extends between the eastern highly drained and the western slightly drained Eocene Plateaus. The River Nile gets very close to the eastern ridge of the valley. The eastern plateau extends from wadi El Saririia at the southern part up to wadi Awlad El Shaikh at the Northern part of the study area. Several wadis that drain the plateau dissect it, in part, into elongated northwest or southwest trends. In the western desert, a relatively wide plain separates the undulated uniform surfaced western plateau from the valley (Fig. 1). The eastern and western plateaus are formed of massive yellow limestone, chalky limestone, marl and shale of Middle Eocene Samalut, Maghagha and Qarara Formations.

The eastern zone of Nile Valley in the investigated area, with a part of the eastern plateau represents the future urban extension of crowded population sites on the western side of Nile River and this area plays an important role for reclamation purpose, where the reclamations are essentially depending on groundwater. Hence, the present study deals with the application of geoelectrical resistivity technique for delineating groundwater aquifers in the investigated area and introducing the suitability of some recommended sites for drilling wells by constructing a priority maps for exploitation in the investigated area.

\section{Geomorphological Setting:}

According to Said (1981), the following geomorphological features (landforms) can be recognized in the study area and its vicinities (Fig. 2):

1. Young Alluvial Plains of Nile Valley (Holocene Silty clay). 
2. Old Alluvial Plains of Nile Valley (Quaternary Sand and Gravel).

3. Fanglomerate.

4. Calcareous Structural Limestone Plateau and their Sloping Boundaries (Middle Eocene Limestone).

5. Sand Dunes.

6. Hydrographic Patterns.

\section{Geological Setting:}

El Minia district and its vicinities are essentially covered by sedimentary rocks which range in age from Middle Eocene to Recent (Fig. 3). This area was studied by several workers: e.g. Attia (1954), Said (1962, 1981 and 1990), Youssef, M I. (1968), Omara et al. (1973 and 1977), Tamer et al (1974), Boukhary and Abdel Malik (1983), Strougo et al (1990), EGSMA et al (2005).

According to EGSMA et al (2005), the study area includes six mappable rock units of Middle Eocene age. These units are composed mainly of limestone rocks and described from oldest to youngest as the following:

\section{A. Samalut Formation:}

Samalut Formation consists of white limestone and chalky limestone with some marl and claystone interbeds. Samalut Formation underlies Maghagha Formation and stratigraphically overlies El Minia Formation. The average thickness of Samalut Formation reaches about $160 \mathrm{~m}$.

\section{B. Maghagha Formation:}

It consists of limestone and marl with arenaceous marls and shales at the base, intercalated with few calcareous sandstone. The average thickness of Maghagha Formation reaches about $60 \mathrm{~m}$.

\section{Qarara Formation:}

It is consists of green and brick-red to brown shale grading upwards into arenaceous marls and siltstone with nummulitic limestone beds. The average thickness of Qarara Formation reaches about $170 \mathrm{~m}$.

\section{El Mereir Formation:}

It consists of chalky limestone with some chert bands and nodules.

\section{E. Sannur Formation:}

This Formation overlies El Mereir Formation. It consists of bioclastic limestone, mediumbedded with some normality thin beds or banks.

\section{F.Qazzun Formation:}

It is consists of chalky limestone with siliceous, dolomitic and nummulitic limestone interbeds.

\section{Structural Setting:}

Generally, the central part of Egypt is a region of the simple surface geological structure represented mainly by the northerly gently dipping tertiary strata of wide regional extends and fairly uniform lithology. Moreover, the central Egypt forms a distinct geomorphological and structural unit, which is characterized by a number of northeast-southwest and northwest-southeast faults and associated with the structural configuration of the Nile valley itself.

Said (1962) stated that the valley was probably eroded on fault lines. In (1981) he added that the valley is bounded on both sides by steep slopes made up of Eocene limestone, most probably accompanied by normal faults. Major normal faults have a general NW_SE and NE_SW directions. These faults are observable on the surface as well as they are encountered from subsurface borehole data below the Quaternary deposits Said (1990). The large numbers of faults give rise to other structural features such as horsts and grabens.

\section{Methodology:}

A total of forty-four Vertical Electrical Soundings were conducted along the different wadis in the investigated area using schlumberger array with a maximum half current electrode spacing $(\mathrm{AB} / 2)$ of $700 \mathrm{~m}$ this electrode separation provides to be sufficient to reach the required depth that fulfills the aim of the study. In order to verify the geoelectrical interpretation results, some of the sounding measurements were carried out beside or near some of existing wells, which lithological and hydrological data are available. These vertical electrical soundings have been carried out by ABEM terrameter SAS 
$1000 \mathrm{C}$ as Swedish apparatus. Geoelectrical resistivity data were interpreted quantitatively to get the best results where the apparent resistivity measurements at each station were plotted against half current electrode spacing $(\mathrm{AB} / 2)$ on a bi-logarithmic graph sheets. These data were fed into a computer to build a resistivity model in an iterative forward modeling technique using the IPI2Win computer program (2003). From interpreted results (layer resistivity and thickness); geoelectric sections were drawn using Grapher software. Also, both of true resistivity and isopach contour maps of water bearing layers were created based on these data using Surfer soft-

Table 1: Resistivities, Thicknesses Ranges and their Related Lithology.

\begin{tabular}{|c|c|c|c|c|}
\hline Unit & Layer & $\begin{array}{l}\text { Resistivity range } \\
\quad(\text { Ohm m) }\end{array}$ & $\begin{array}{l}\text { Thickness } \\
\text { (m) }\end{array}$ & Lithology \\
\hline \multirow{4}{*}{ "A" } & A1 & $83-9898$ & $0.3-11$ & Gravel, boulders and sands \\
\hline & $\mathrm{A} 2$ & $7-33$ & $1-18$ & Nile silt and clay \\
\hline & A3 & $2-10$ & --- & $\begin{array}{l}\text { Water-bearing sands and gravels with } \\
\text { clay and shale lenses }\end{array}$ \\
\hline & A4 & $119-2689$ & $1-6$ & Old wadi sediments \\
\hline \multirow{3}{*}{ "B" } & $\mathrm{B} 1$ & $458-5430$ & $0.2-20$ & Dry limestone of Qarara Formation \\
\hline & $\mathrm{B} 2$ & $12-35$ & $3-18$ & Marle of Qarara Formation \\
\hline & B3 & $2.3-9$ & $7-38$ & Shale of Qarara Formation \\
\hline \multirow{4}{*}{ "C" } & $\mathrm{C} 1$ & $75-136$ & $15-50$ & $\begin{array}{l}\text { Water-bearing limestone of Maghagha } \\
\text { Formation }\end{array}$ \\
\hline & $\mathrm{C} 2$ & $210-1500$ & $3-25$ & Dry limestone of Maghagha Formation \\
\hline & $\mathrm{C} 3$ & $11-77$ & $5-30$ & $\begin{array}{l}\text { Marly limestone of Maghagha } \\
\text { Formation }\end{array}$ \\
\hline & $\mathrm{C} 4$ & $0.9-9$ & $8.5-78$ & Shale of Maghagha Formation \\
\hline \multirow{5}{*}{ “D” } & D1 & $200-2900$ & $5-38$ & Dry limestone of Samalut Formation \\
\hline & $\mathrm{D} 2$ & $46-153$ & $1.3-5.7$ & $\begin{array}{l}\text { Chalky limestone of Samalut } \\
\text { Formation }\end{array}$ \\
\hline & D3 & $14-26$ & $4-18$ & Claystone of Samalut Formation \\
\hline & D4 & $30-200$ & $19-110$ & $\begin{array}{l}\text { Water-bearing limestone of Samalut } \\
\text { Formation }\end{array}$ \\
\hline & D5 & $2.8-9.8$ & $10-33$ & Shale of Samalut Formation \\
\hline & $50-190$ & --- & $\begin{array}{l}\text { Water-bearing limestone of Minia } \\
\text { Formation }\end{array}$ \\
\hline
\end{tabular}

Table 2: Resistivity, Thickness and Depth to Water Category Ranges for the Samalut Aquifer:

\begin{tabular}{|c|c|c|c|}
\hline Category & $\begin{array}{c}\text { Resistivity }(\rho) \\
\text { Ranges }(\Omega)\end{array}$ & $\begin{array}{c}\text { Thickness (h) } \\
\text { Ranges (m) }\end{array}$ & $\begin{array}{l}\text { Depth to Water } \\
\text { (D) Ranges (m) }\end{array}$ \\
\hline 1 & $30 \leq \rho<87$ & $105 \geq \mathrm{h}>76$ & $10 \leq \mathrm{D}<44$ \\
\hline 2 & $87 \leq \rho<144$ & $76 \geq h>48$ & $44 \leq \mathrm{D} \leq 77$ \\
\hline 3 & $144 \leq \rho \leq 200$ & $48 \geq h \geq 20$ & $77 \leq \mathrm{D} \leq 110$ \\
\hline
\end{tabular}

Table 3: Resistivity and Depth to Water Category Ranges for the EI Minia Aquifer

\begin{tabular}{||c|c|c||}
\hline Category & $\begin{array}{c}\text { Resistivity ( }) \\
\text { Ranges }(\mathbf{\Omega})\end{array}$ & $\begin{array}{l}\text { Depth to Water (D) } \\
\text { Ranges }(\mathbf{m})\end{array}$ \\
\hline 1 & $50 \leq \rho<97$ & $25 \leq \mathrm{D}<75$ \\
\hline 2 & $97 \leq \rho<144$ & $75 \leq \mathrm{D}<125$ \\
\hline 3 & $144 \leq \rho \leq 190$ & $125 \leq \mathrm{D} \leq 175$ \\
\hline
\end{tabular}




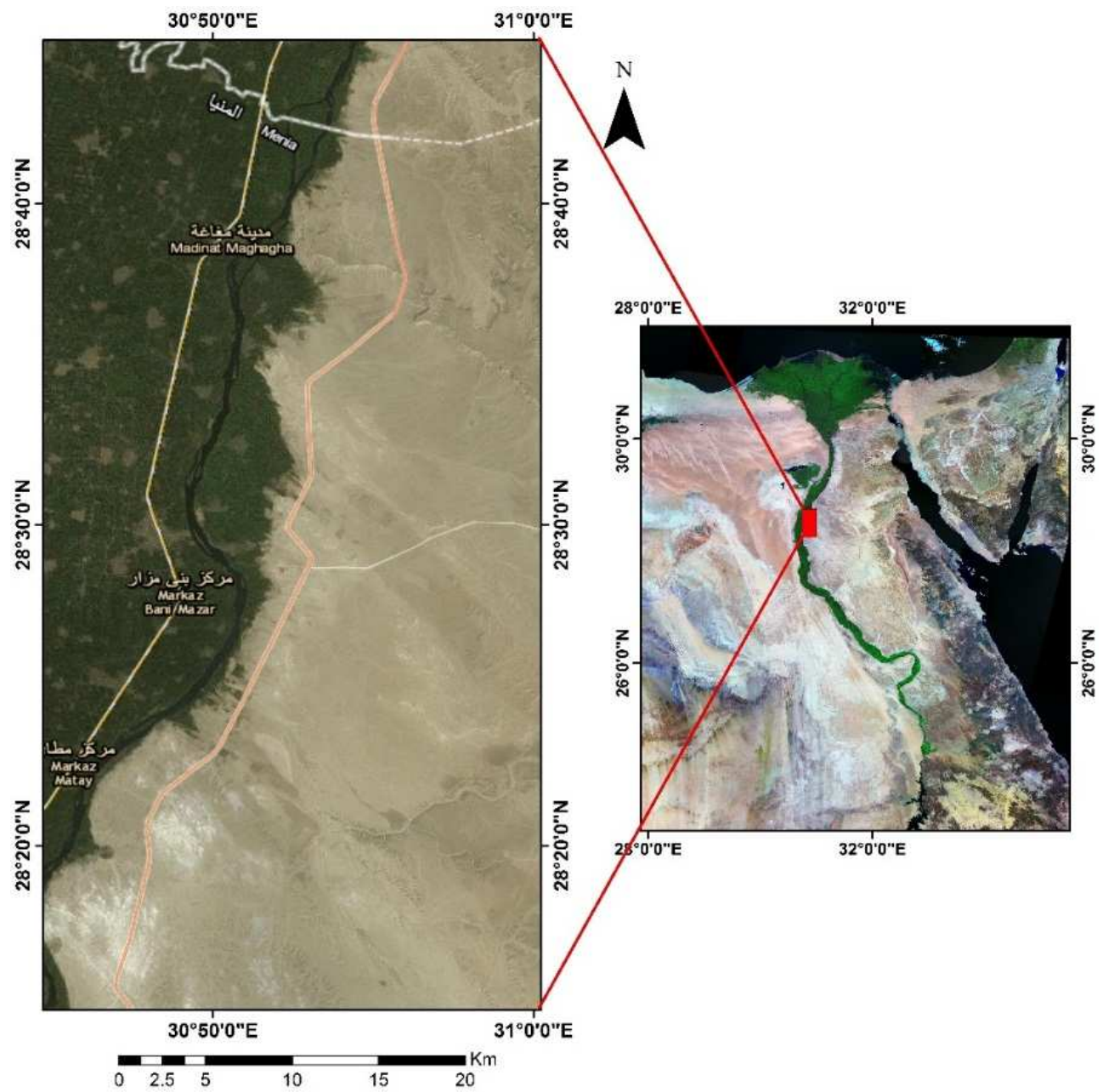

Fig. 1: Google Earth Image Showing the Location of the Investigated Area.

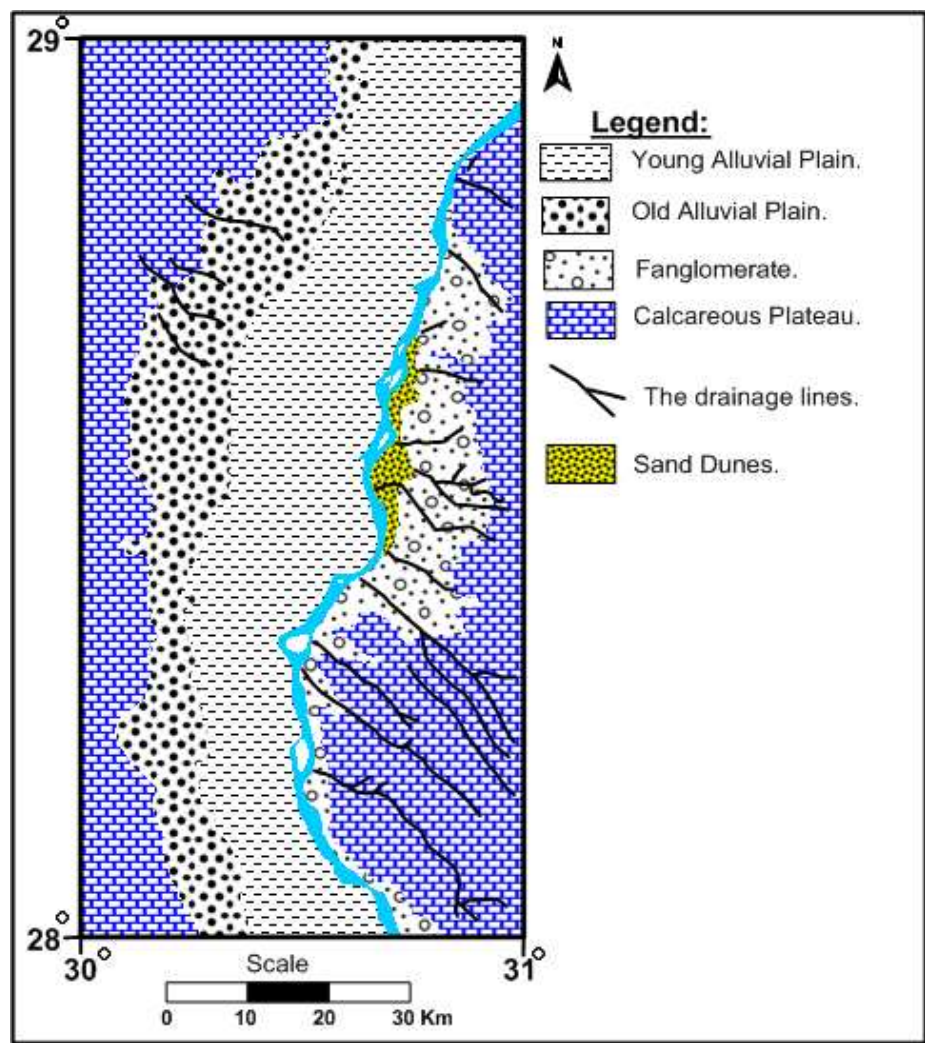

Fig. 2: Geomorphological and Drainage Features of the Study Area and its Vicinities (After Said, 1981) 


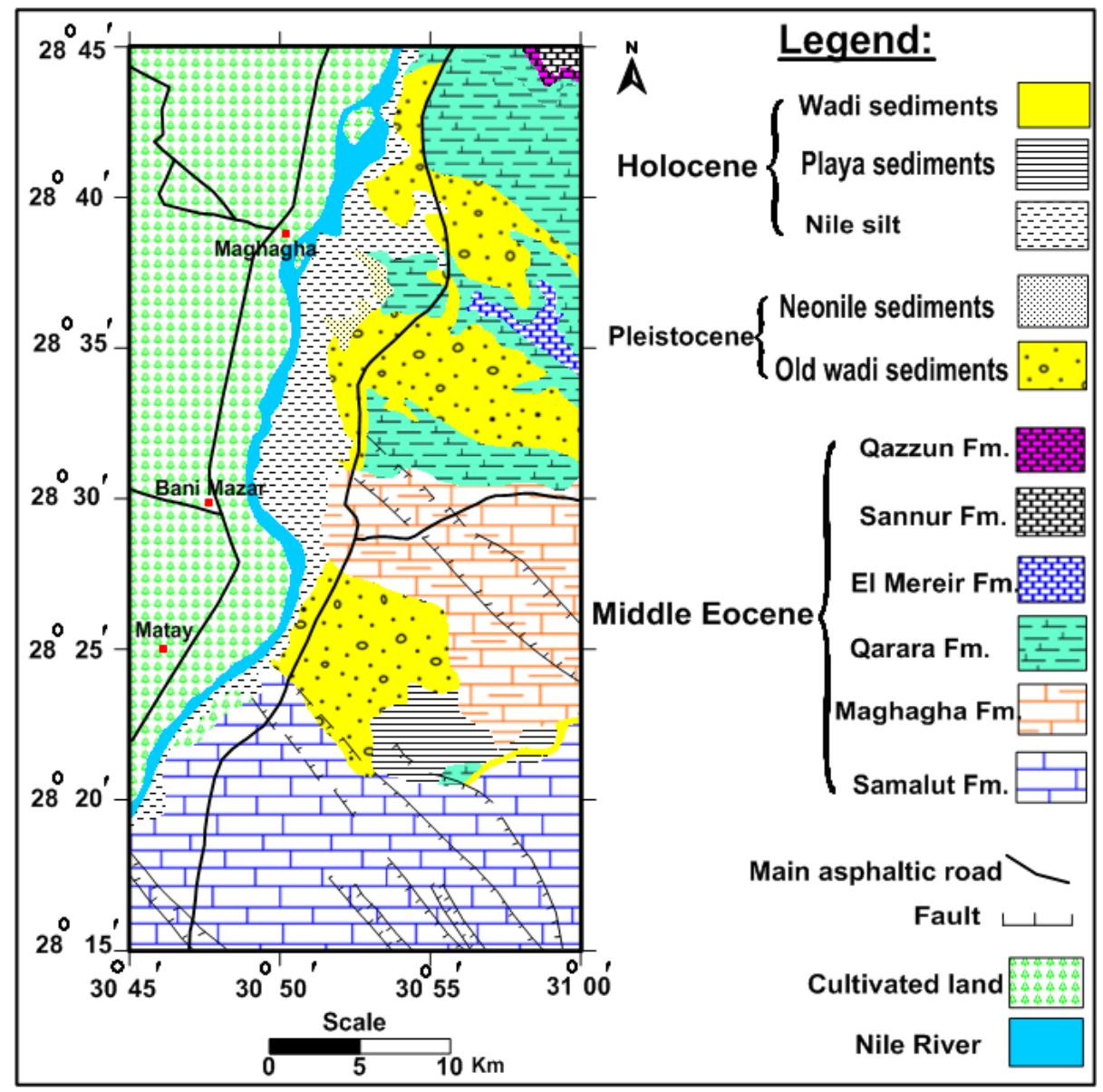

Fig. 3: Geological Map of the Study Area (After EGSMA et al, 2005)

Fig. 4: Distribution of VES's and Cross Sections in the Study Area.

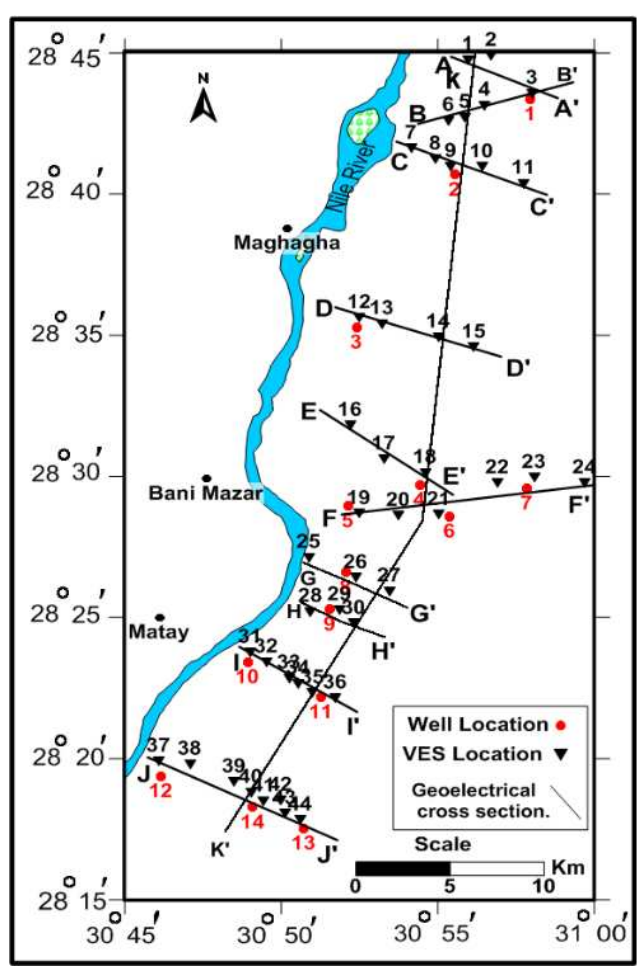


Tharwat $\mathrm{H}$ et al.

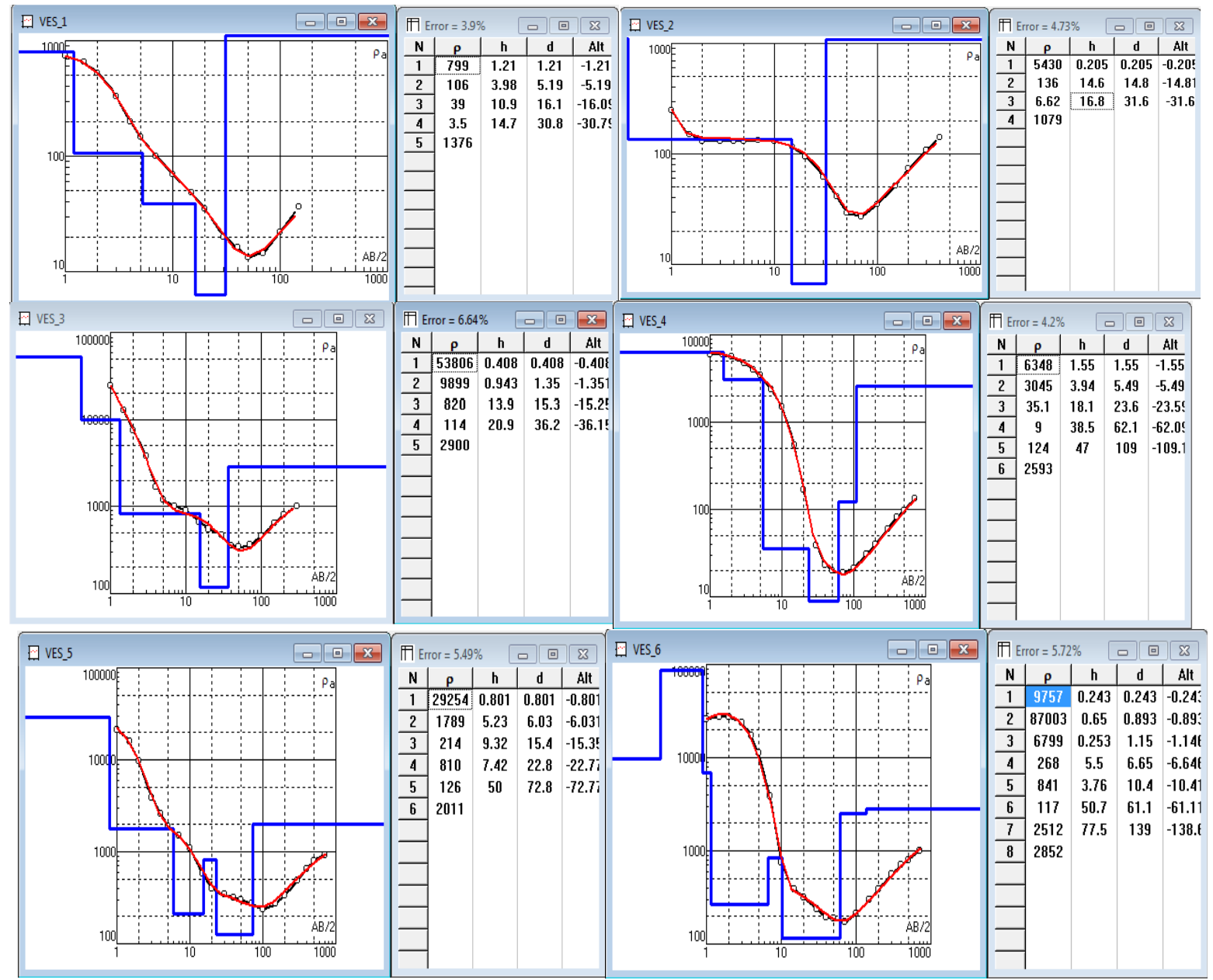

Fig. 5: Some of the Interpreted Vertical Electrical Sounding Curves with the True Resistivities ( $\rho)$ and Thicknesses (h) of Each Layer using IPI2Win Program

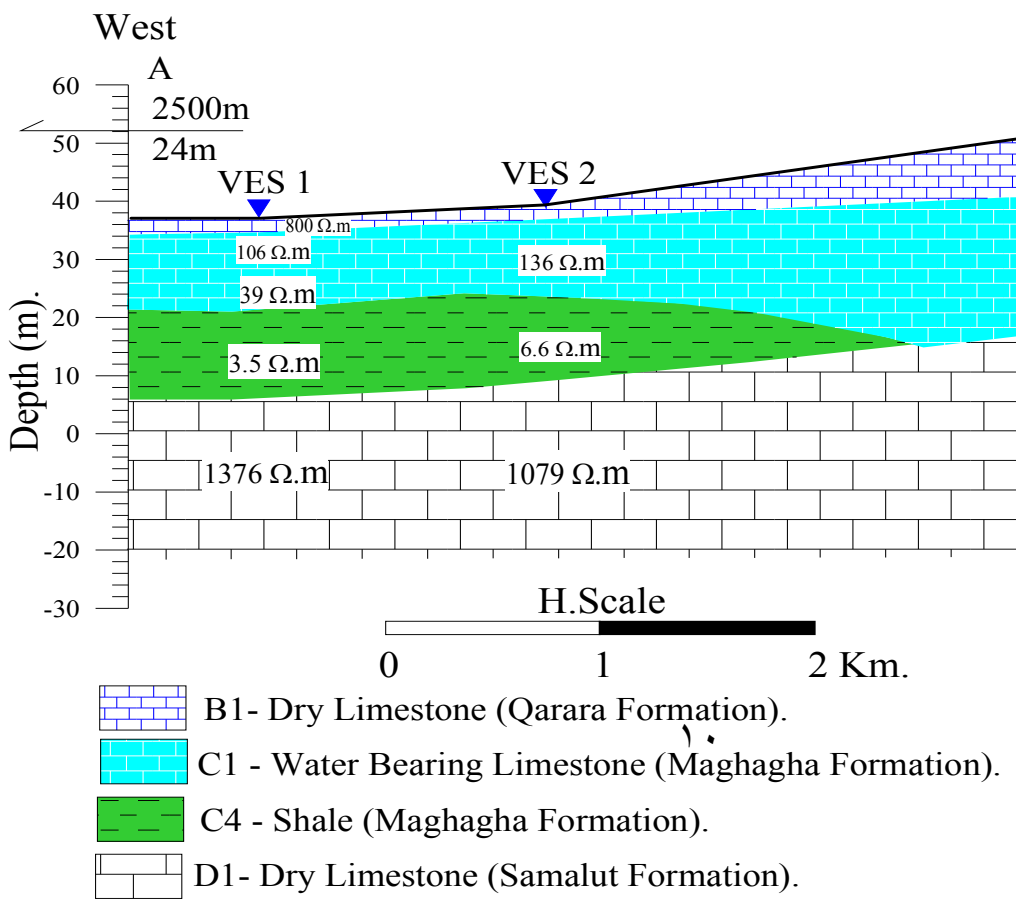

$\nabla$ Vertical Electrical Sounding .

$\bigcirc$ Well.

Distance to nile river Nile river water level

Fig. 6: Geoelectric Resistivity Cross-Section A-A' 


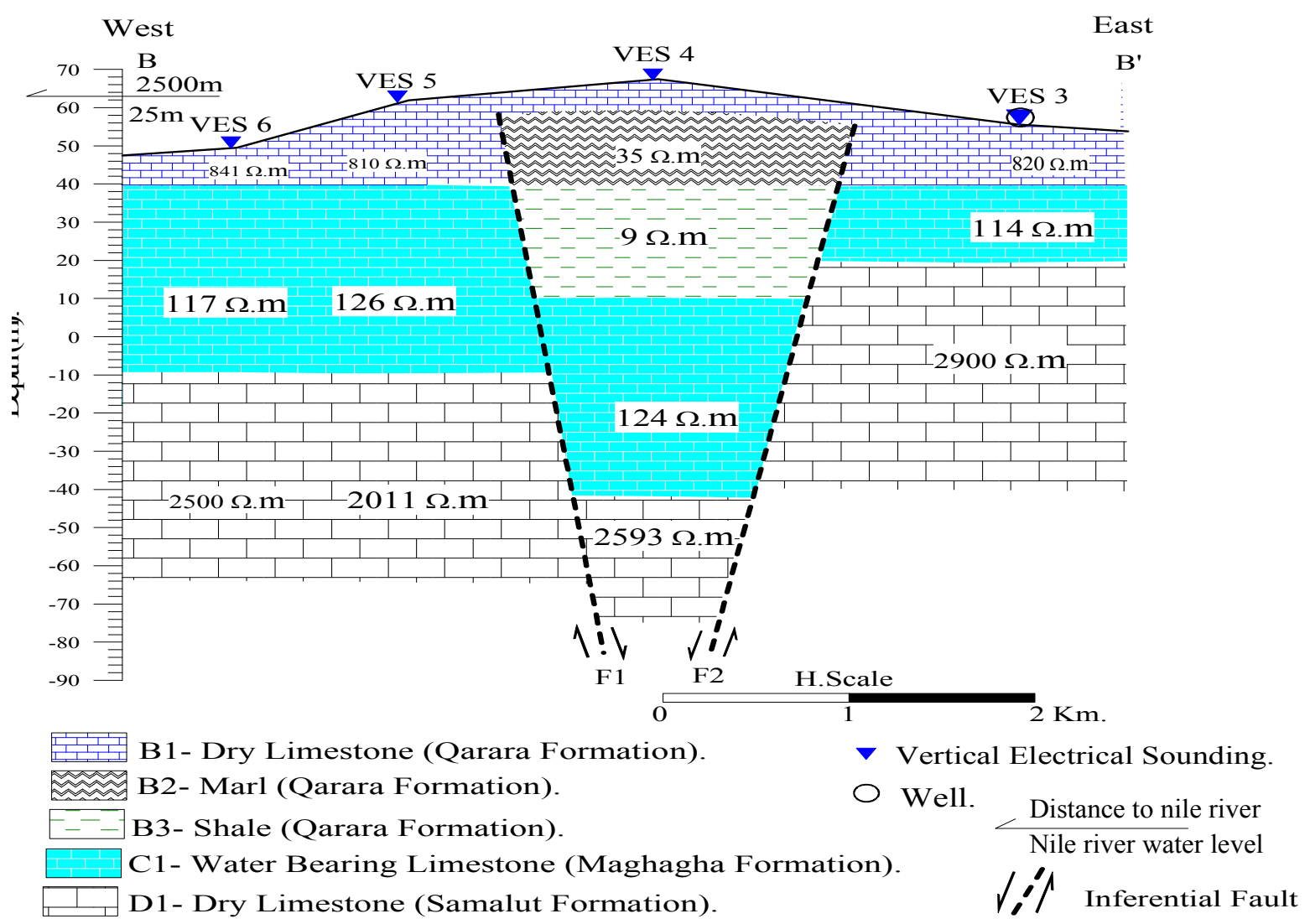

Fig. 7: Geoelectric Resistivity Cross-Section B-B'

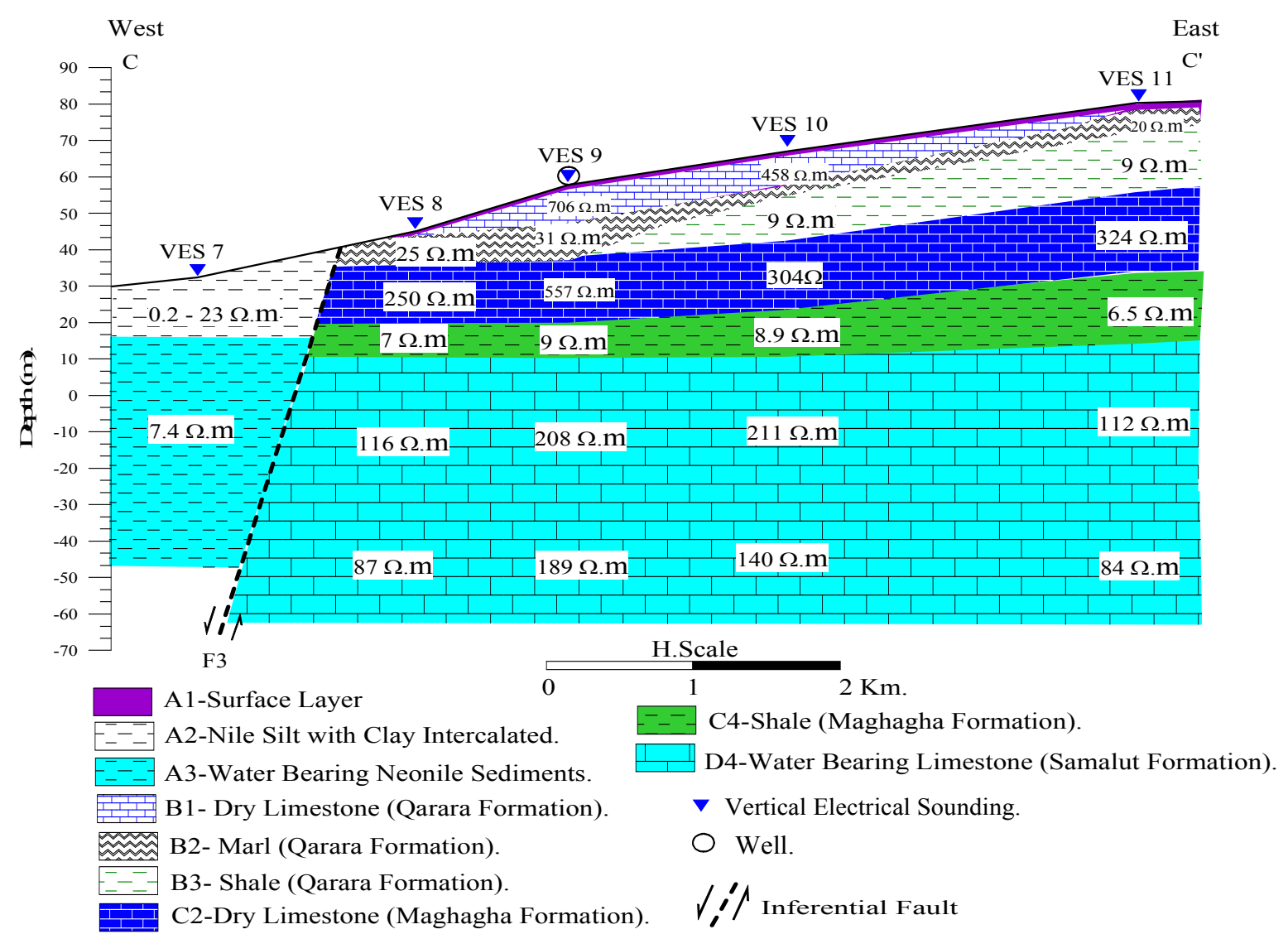

Fig. 8: Geoelectric Resistivity Cross-Section C-C' 


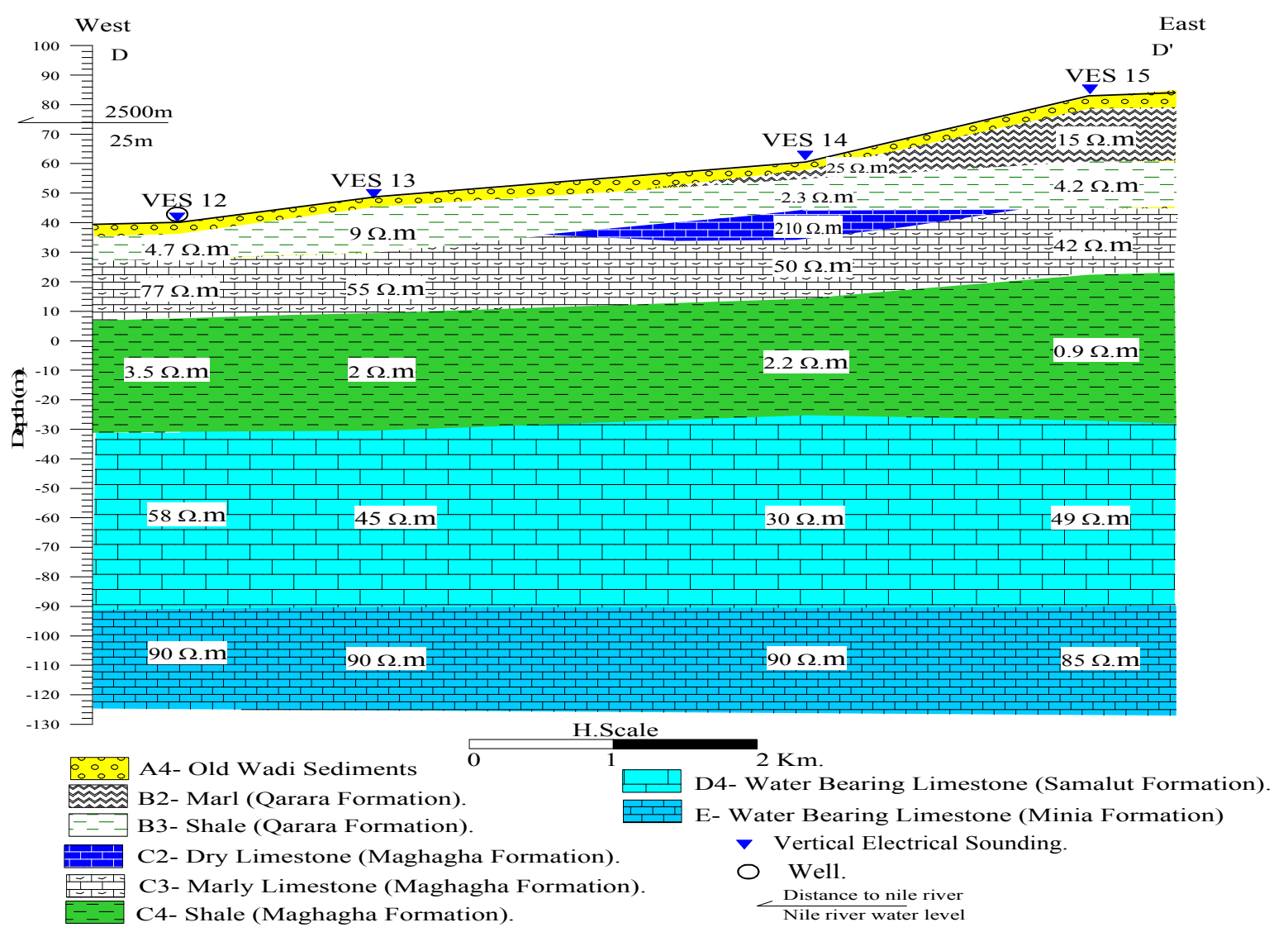

Fig. 9: Geoelectric Resistivity Cross-Section D-D'

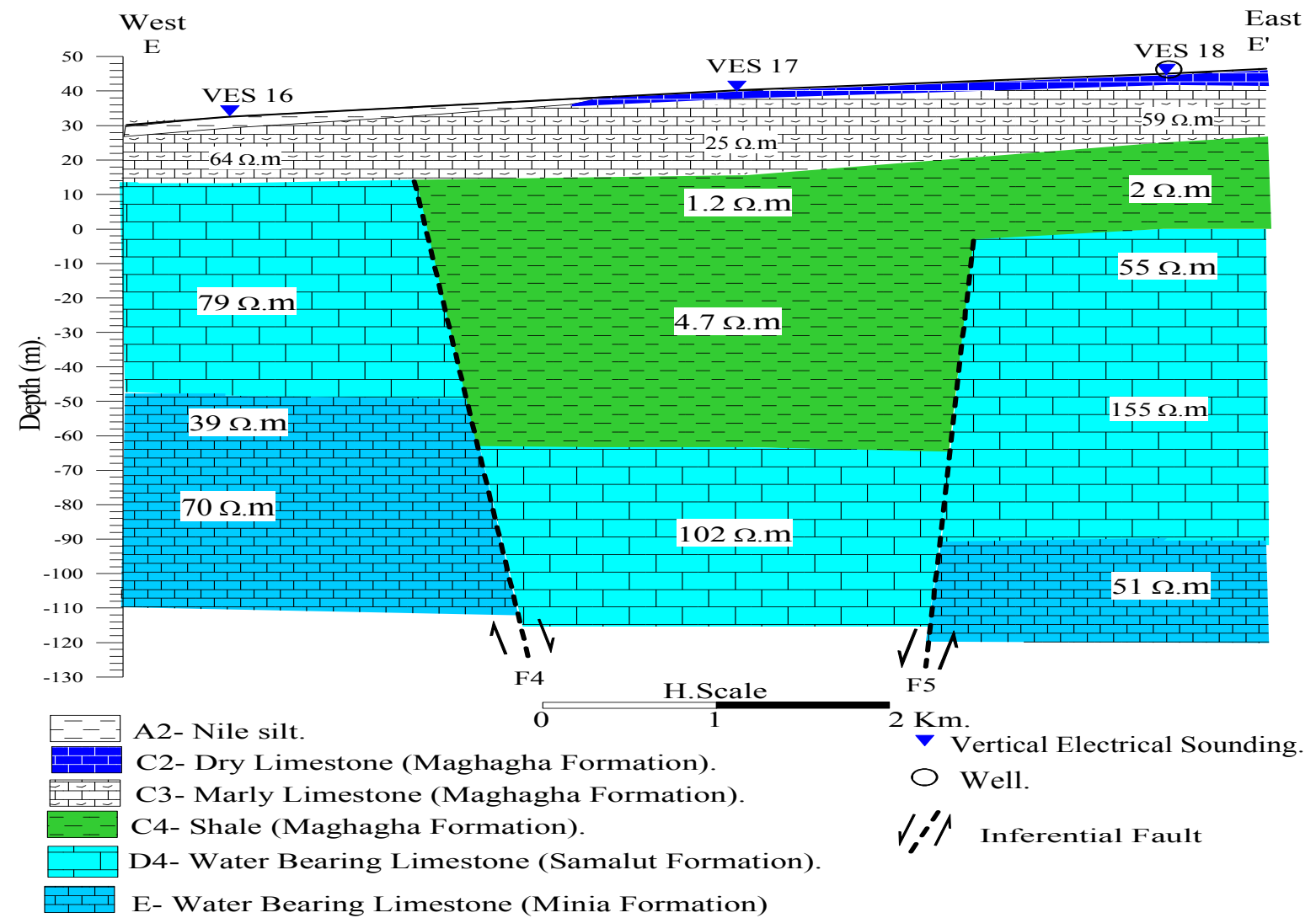

Fig. 10: Geoelectric Resistivity Cross-Section E-E' 


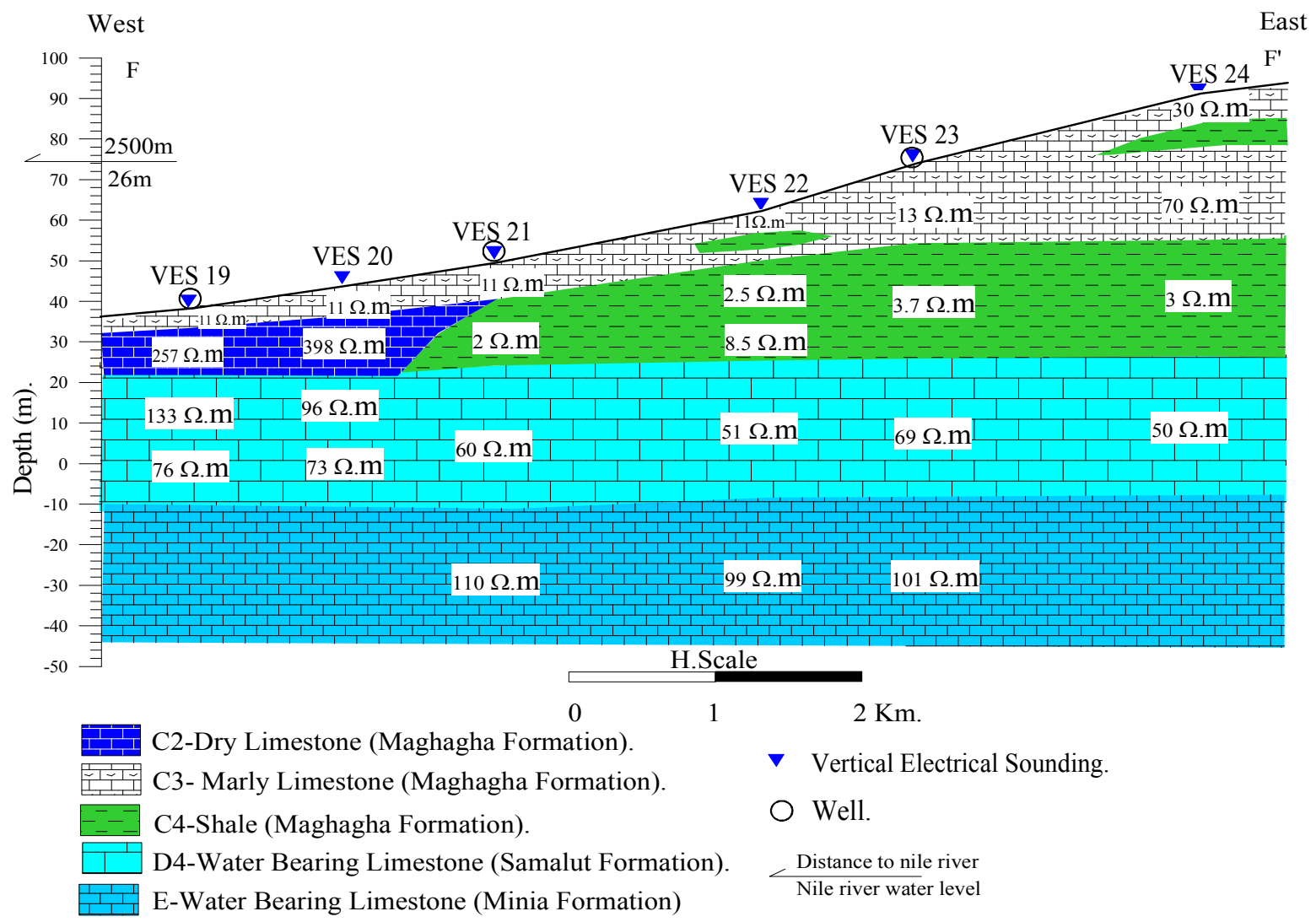

Fig. 11: Geoelectric Resistivity Cross-Section F-F'

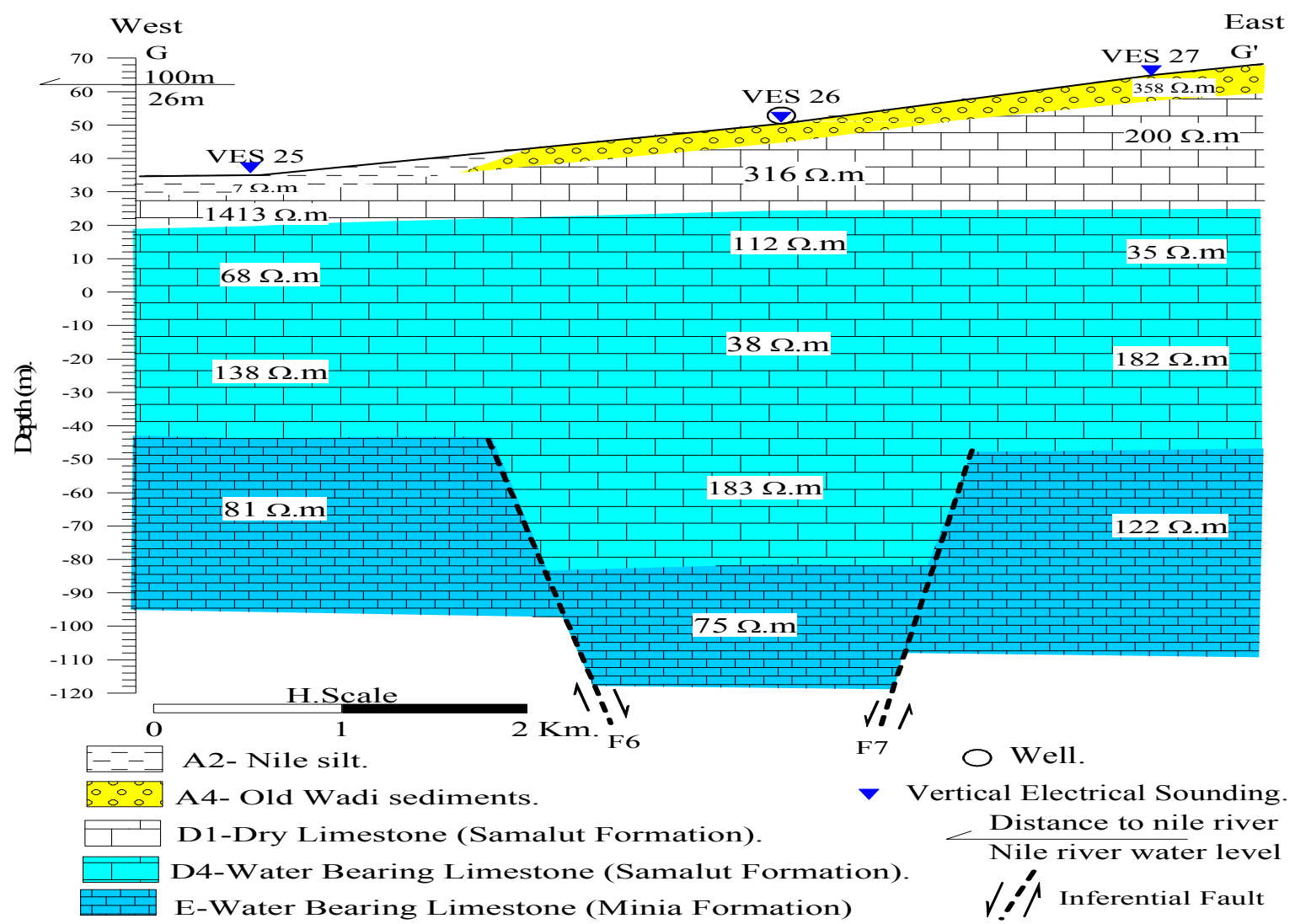

Fig. 12: Geoelectric Resistivity Cross-Section G-G' 


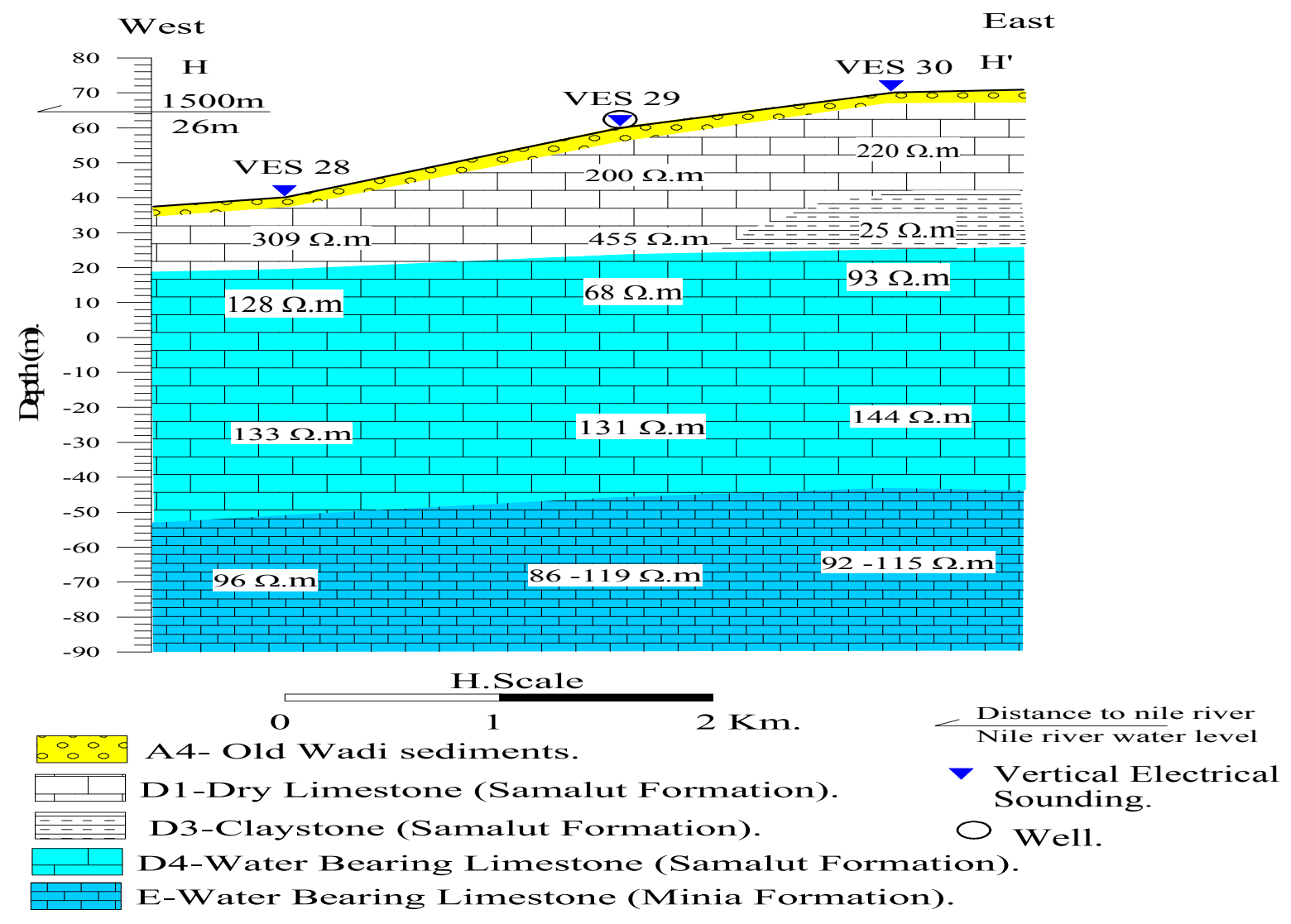

Fig. 13: Geoelectric Resistivity Cross-Section H-H'

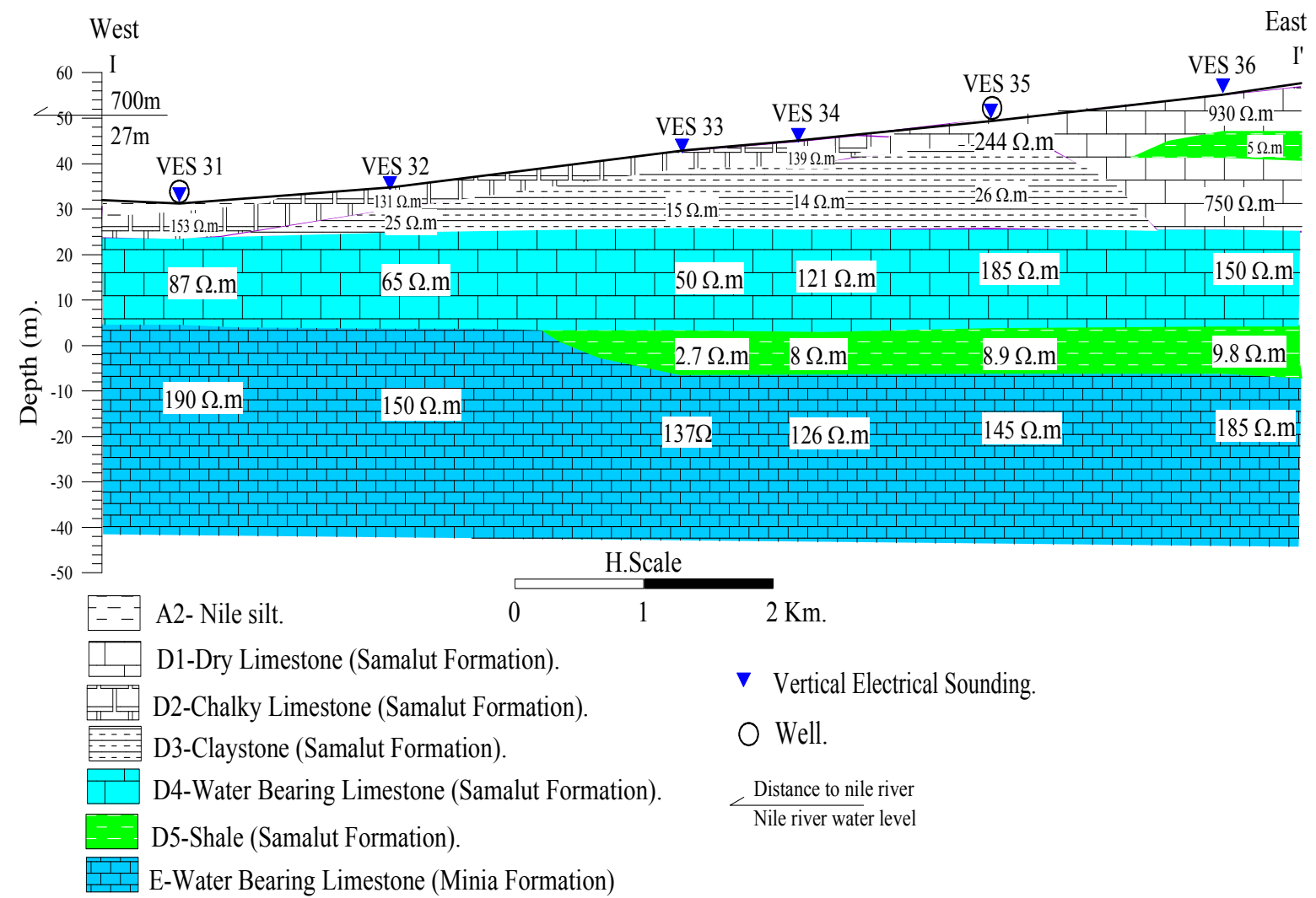

Fig. 14: Geoelectric Resistivity Cross-Section I-I' 


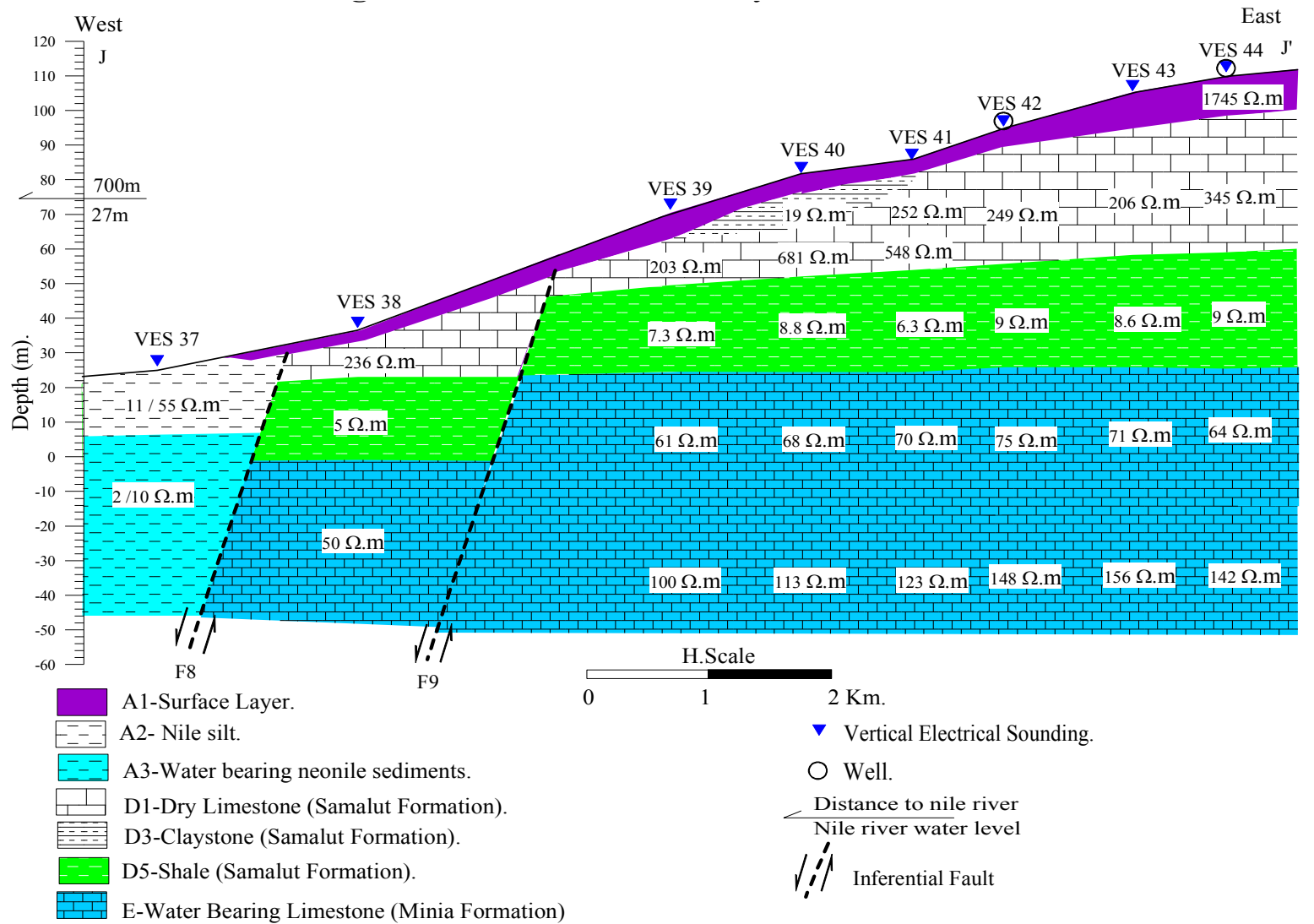

Fig. 15: Geoelectric Resistivity Cross-Section J-J'

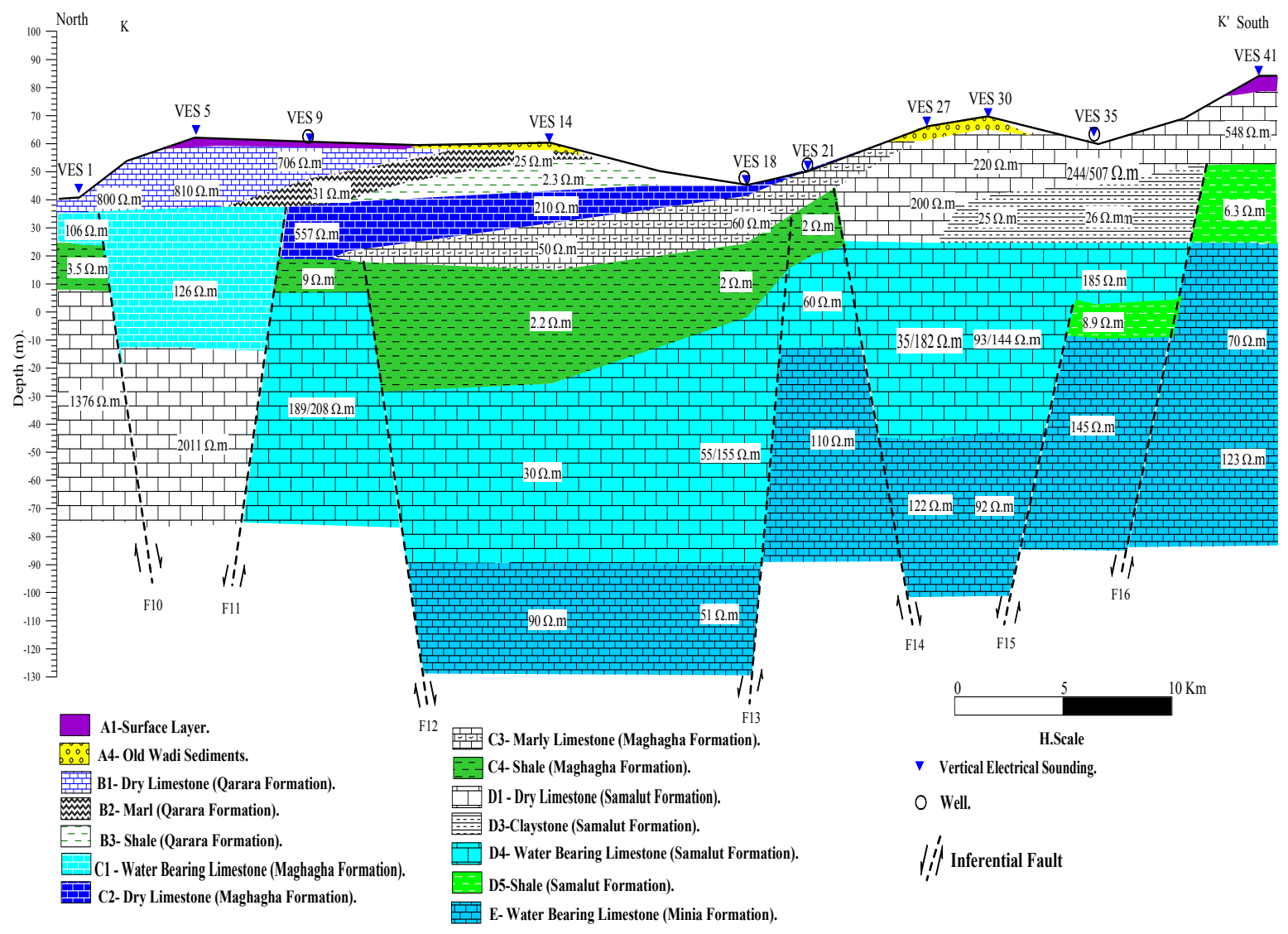

Fig 16: Geoelectric Resistivity Cross-Section K-K' 
Tharwat $\mathrm{H}$ et al .

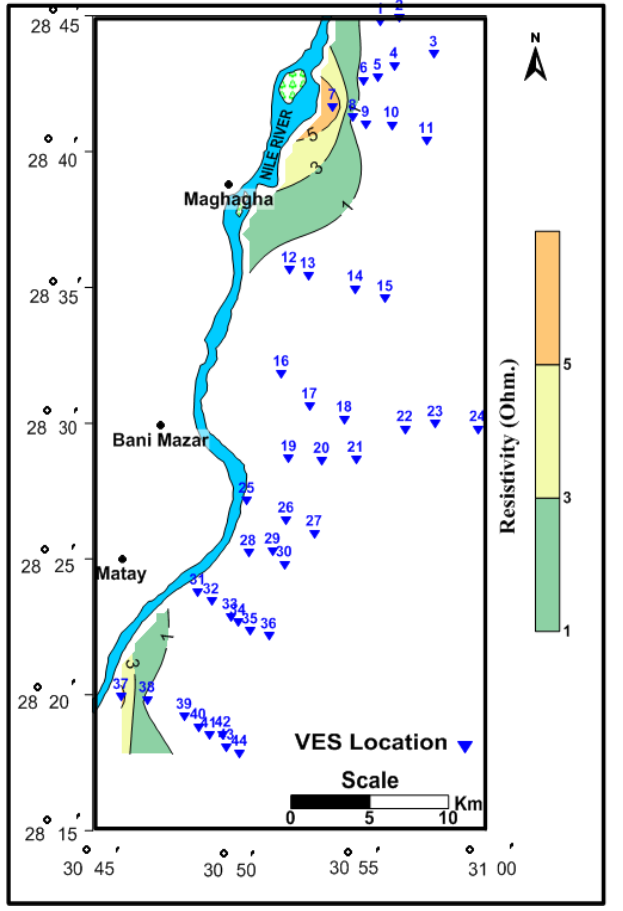

Fig. 17: True Resistivity Contour Map of the Layer (A3).

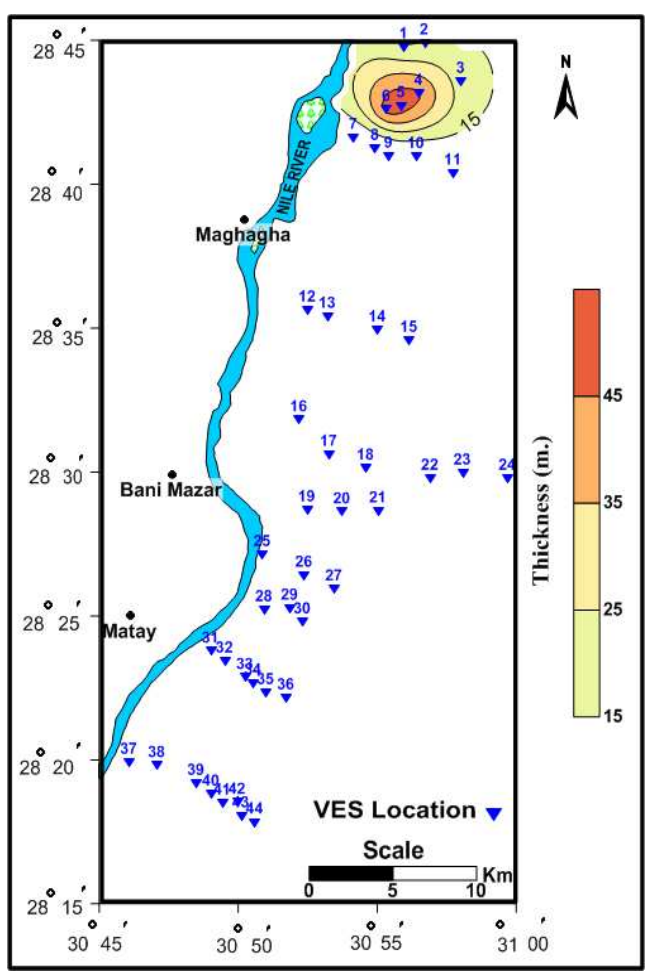

Fig. 19: Isopach Map of the Layer (C1).

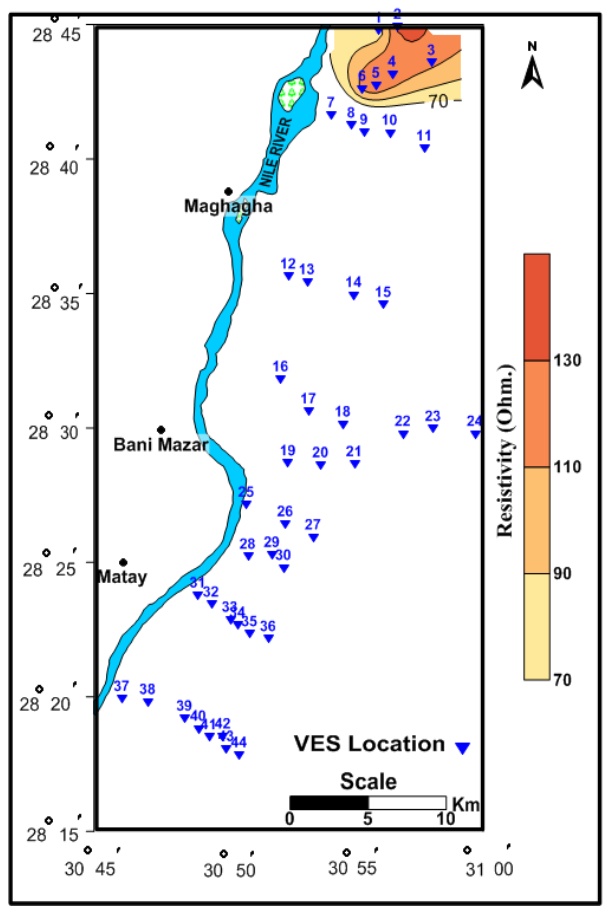

Fig. 18: True Resistivity Contour Map of the Layer $(\mathrm{C} 1)$.

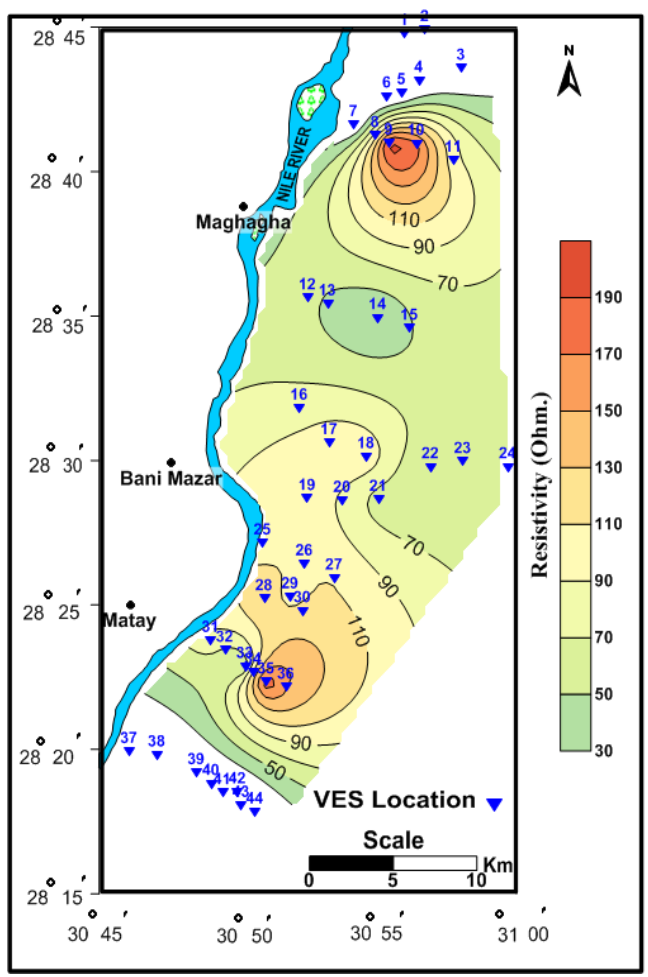

Fig. 20: True Resistivity Contour Map of the Layer (D4) 


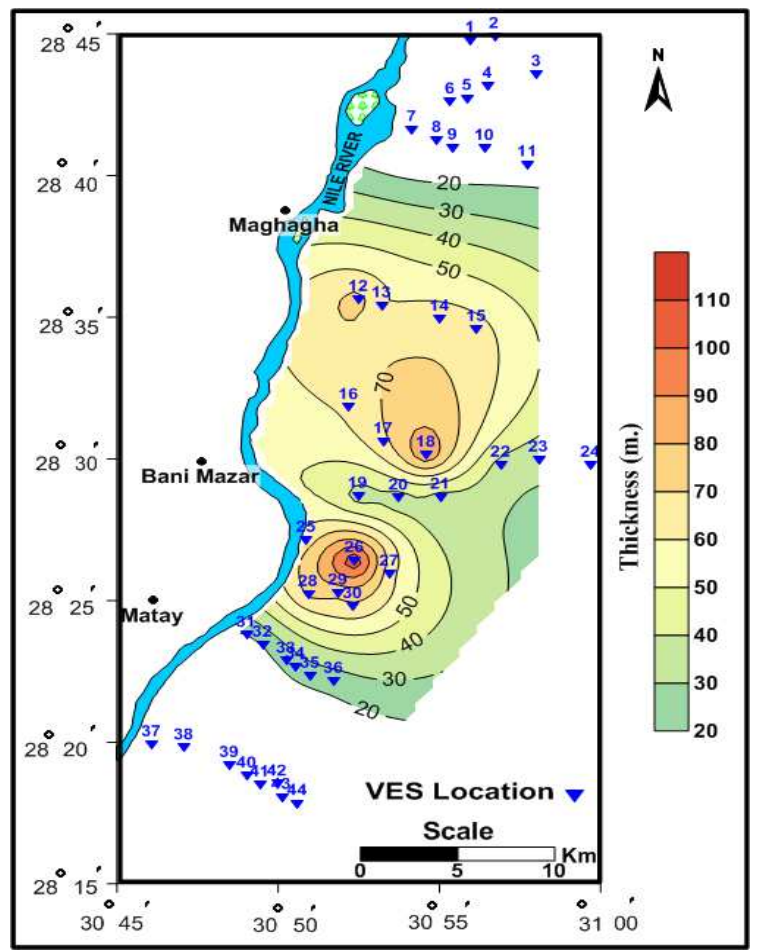

Fig. 21: Isopach Map of the Layer (D4).

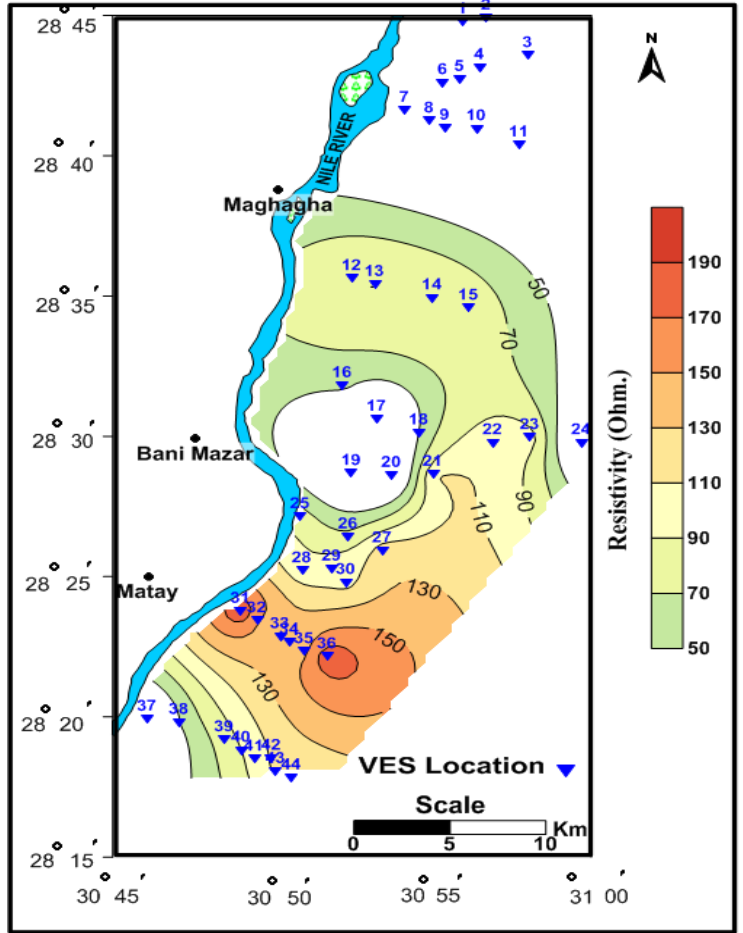

Fig. 22: True Resistivity Contour Map of the Last Layer (E).

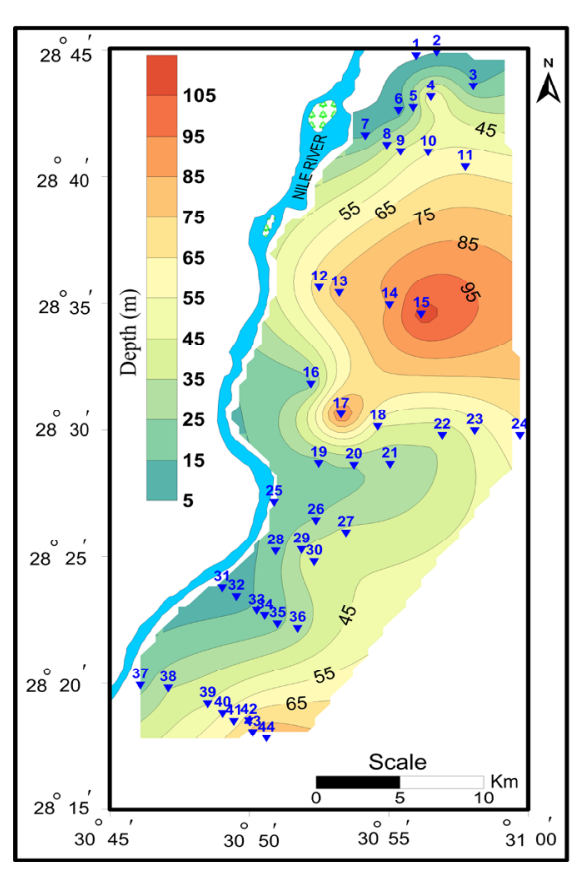

Fig. 23: Depth to Water Bearing Formations Contour Map.

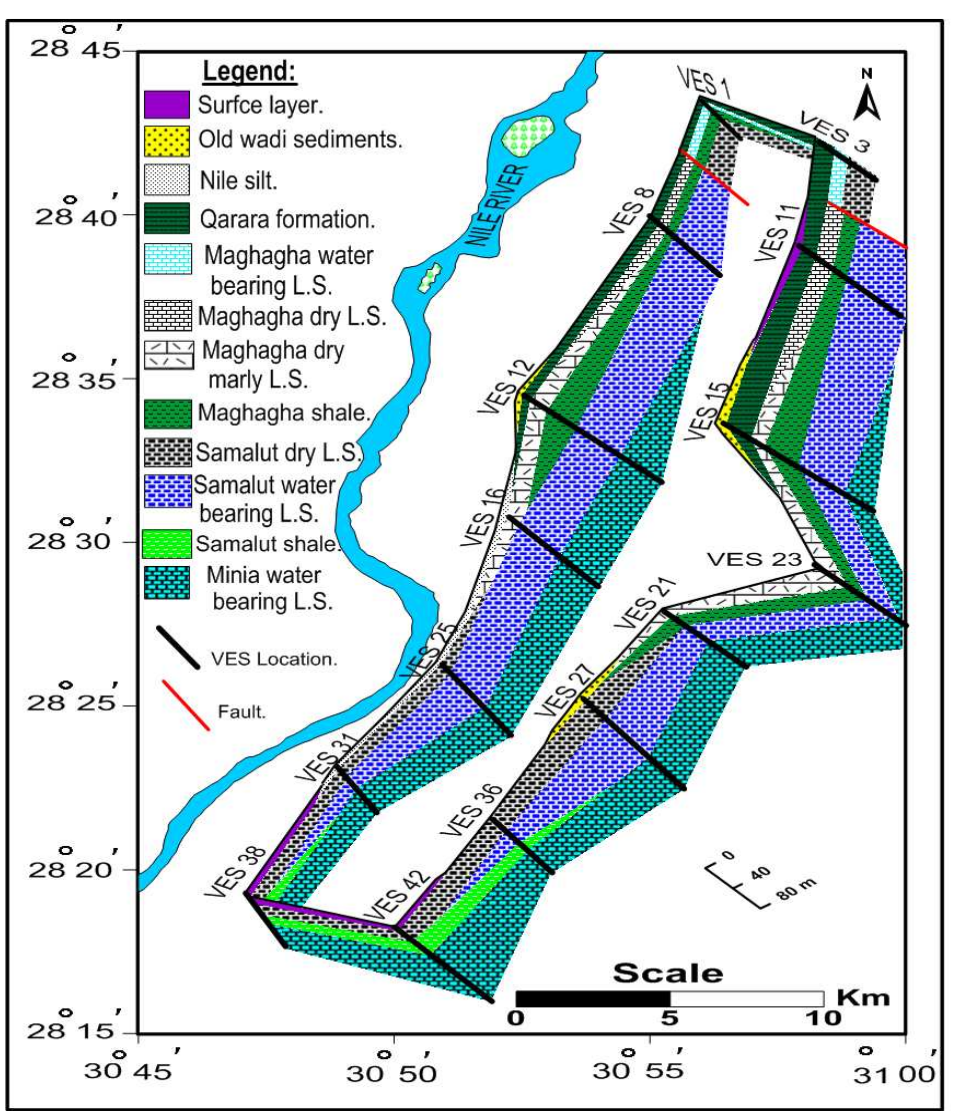

Fig. 24: Panel Diagram Showing Subsurface Geoelectrical Facies Changes. 
Tharwat $\mathrm{H}$ et al .

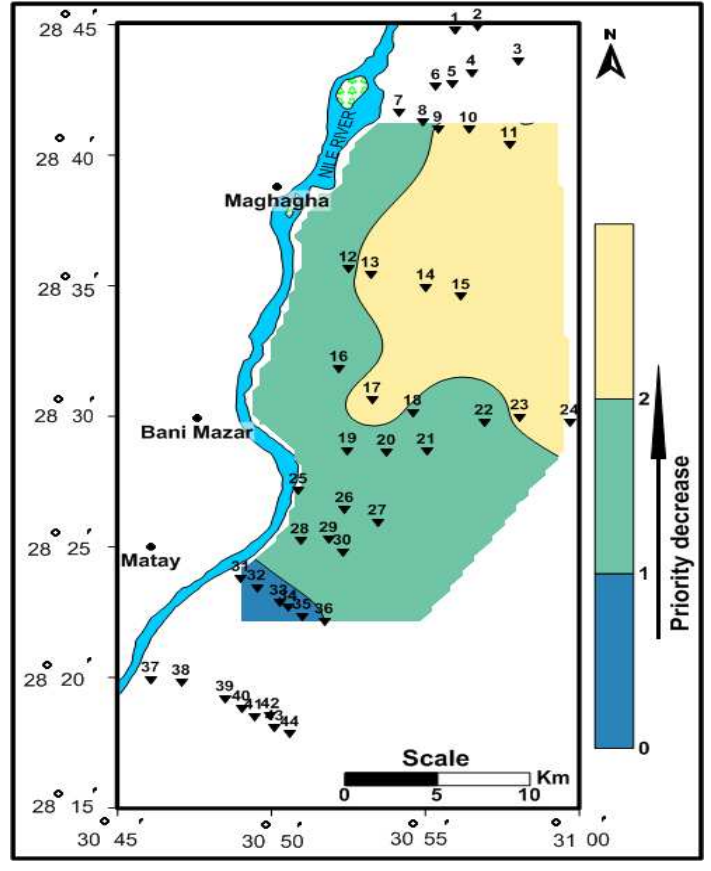

Fig. 25: Priority Map for Samalut Aquifer. ware.

\section{DISCUSSION AND RESULTS}

The location of the measured vertical electrical soundings are illustrated in )Fig. 4), some of the interpreted vertical electrical sounding curves with the true resistivities and thicknesses of the study area are shown in )Fig. 5).

\subsubsection{Geoelectrical Cross Sections}

Based on the results of the interpreted vertical electrical soundings, eleven geoelectrical cross sections (Fig. 4) have been constructed as (Fig. No. 6 to 16). The aim of these sections is to show geoelectric layers and the geometry of the aquifers and its extension in the area. These sections reflect both lateral and vertical variations in lithology according to resistivity. The bore holes (where these wells drilled by villagers) which present in the area were also used to calibrate the geoelectrical inFormation.

The quantitative interpretation of the resistivity soundings led to detection of five main geoelectrical units which divided into layers. The ranges of resistivities and thicknesses of each unit are listed in (table 1). A description of these units is given as the following:

\section{-The First Geoelectrical Unit (A):}

This unit differentiated into four layers A1,

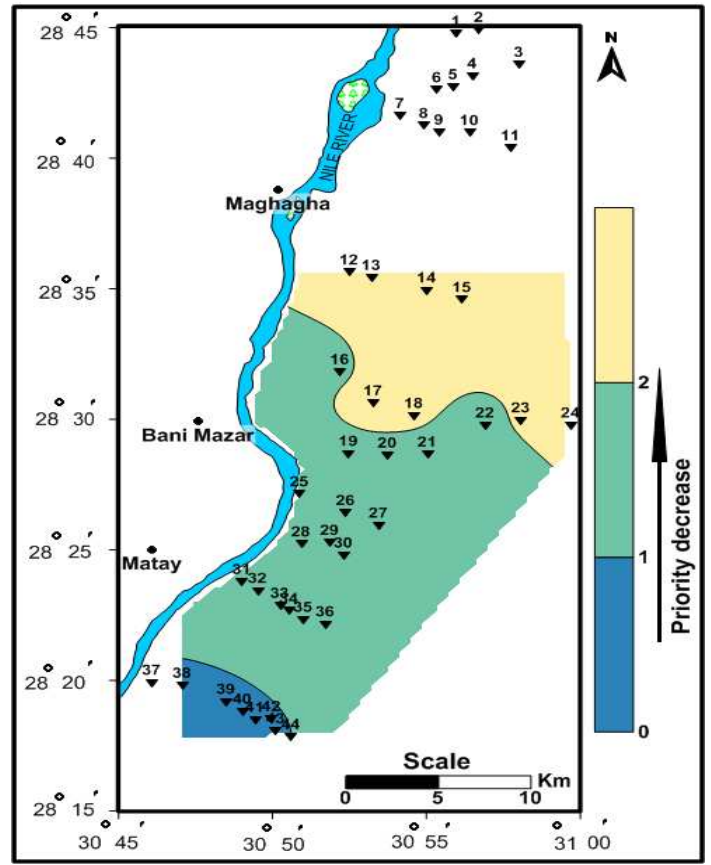

Fig. 26: Priority Map for Minia Aquifer.

A2, A3 and A4 and their equivalent facies of Quaternary deposits.

a- The geoelectrical layer (A1) is observed at northern and southern parts of the study area and not observed at the central part. The surface resistivity values are ranged between 83 and 9898 $\Omega$.m corresponds to gravels, boulders and sands. The thickness of this layer varies from 0.3 to 11 $\mathrm{m}$.

b- The geoelectrical layer (A2) is observed along the eastern part of Nile River in the study area. This layer displays a relatively low resistivity value varies from $7 \Omega$.m at VES No. 25 to 33 $\Omega . m$ at VES No. 37 corresponds to Nile silt and clay. The thickness of this layer varies from $1 \mathrm{~m}$ at VES No. 31 to $18 \mathrm{~m}$ at VES No. 37.

c- The third geoelectrical layer (A3) is observed at northern and west southern parts of the study area at VES's No. 7 and 37. This layer displays a relatively low resistivity value varies from 2 to $10 \Omega$.m corresponds to water bearing neonile deposits which consist of sands and gravels with clay and shale lenses and represents the first aquifer in the study area.

d- The fourth geoelectrical layer (A4) is observed at Wadi El Sharawna area between central and northern parts and present also at the El 
Salam new village between central and southern parts of the study area. This layer has resistivity values ranging from 119 to $2689 \Omega$.m corresponds to dry old wadi sediments. There are some lower values than $119 \Omega$.m which observed at VES's No. 26 and 29 as 27 and $35 \Omega . m$ respectively. The thickness of this layer varies from $1 \mathrm{~m}$ at VES No. 14 to $6 \mathrm{~m}$ at VES No. 12.

\section{- The Second Geoelectrical Unit (B):}

This unit is located underlying the first geoelectrical unit which differentiated into three layers B1, B2 and B3 and their equivalent facies of Qarara Formation of Middle Eocene.

a- The geoelectrical layer (B1) is observed at a northern part of the study area. The resistivity values of this layer ranging from $458 \Omega . \mathrm{m}$ at VES No. 10 to $5430 \Omega$.m at VES No. 2 corresponds to the dry limestone. The thickness of this layer ranges between $0.2 \mathrm{~m}$ at VES No. 2 and $20 \mathrm{~m}$ at VES No. 5.

b- The geoelectrical layer (B2) is observed at an east-northern part of the study area. The resistivity values of this layer ranging from $12 \Omega . \mathrm{m}$ at VES No. 10 to $35 \Omega . \mathrm{m}$ at VES No. 4 corresponds to marl. The thickness of this layer varies from $3 \mathrm{~m}$ at VES No. 10 to $18 \mathrm{~m}$ at VES No.4.

c- The geoelectrical layer (B3) is observed at a northern part of the study and it displays relatively low resistivity values varies from 2.3 to 9 $\Omega . m$ corresponds to shale. The thickness of this layer varies from $7 \mathrm{~m}$ at VES No. 12 to $38 \mathrm{~m}$ at VES No. 4.

\section{-The Third Geoelectrical Unit (C):}

This unit is located underlying the second geoelectrical unit which differentiated into four layers $\mathrm{C} 1, \mathrm{C} 2, \mathrm{C} 3$ and $\mathrm{C} 4$ and their equivalent facies of Maghagha Formation of Middle Eocene.

a- The geoelectrical layer (C1) is observed at the extremely northern part of the study area at VES's No. 1 to 6 which cover a small part of the study area. It displays relatively medium resistivity values varies from 75 to $136 \Omega$.m corresponds to water-bearing limestone, which represents the second aquifer in the study area. The thickness of this layer varies from $15 \mathrm{~m}$ at VES No. 1 to $50 \mathrm{~m}$ at VES No. 6. b- The geoelectrical layer (C2) is observed at the northern and central parts of the study area which cover a small part of the study area. The resistivity value of this layer varies from 210 to 1500 S.m corresponds to dry limestone. The thickness of this layer varies from $3 \mathrm{~m}$ at VES No. 15 to $25 \mathrm{~m}$ at VES No. 11.

c- The geoelectrical layer (C3) is observed at the area between northern and central parts of the study area. The resistivity value of this layer varies from 11 to $77 \Omega$.m corresponds to marly limestone. The thickness of this layer varies from $35 \mathrm{~m}$ at VES No. 20 to $30 \mathrm{~m}$ at VES No. 24.

d- The geoelectrical layer (C4) is observed at northern and central parts of the study area which represents a wide distribution in the study area. This layer displays relatively low resistivity varies from 0.9 to $9 \Omega$.m corresponds to shale. The thickness of this layer varies from $8.5 \mathrm{~m}$ at VES No. 9 to $78 \mathrm{~m}$ at VES No. 17.

\section{- The Fourth Geoelectrical Unit (D):}

This unit is located underlying the third geoelectrical unit which differentiated into five layers D1, D2, D3, D4 and D5 and their equivalent facies of Samalut Formation of Middle Eocene.

a- The geoelectrical layer (D1) is observed at the extremely northern part and southern part of the study area. This layer displays relatively high resistivity values ranging between 200 and 2900 $\Omega . m$ correspond to dry limestone. The thickness of this layer varies from $5 \mathrm{~m}$ at VES No. 35 to 38 $m$ at VES No. 44.

b- The geoelectrical layer (D2) is observed at a southern part of the study area which represents a small distribution in the study area. This layer has resistivity values ranging between 46 and $153 \Omega . m$ corresponds to chalky limestone. The thickness of this layer varies from $1.3 \mathrm{~m}$ at VES No. 33 to $5.7 \mathrm{~m}$ at VES No. 31 .

c- The geoelectrical layer (D3) is observed at the area between southern and central parts of the study area which represents a small distribution in the study area. This layer has resistivity values ranging between 14 and $26 \Omega$.m corresponds to claystone. The thickness of this layer varies from $4 \mathrm{~m}$ at VES No. 32 to $18 \mathrm{~m}$ at VES No. 30 . 
d- The geoelectrical layer (D4) covers the most parts of the study area. It has resistivity value varies from 30 to $200 \Omega$.m corresponds to water-bearing limestone, which represents the third aquifer in the study area. The thickness of this layer varies from $19 \mathrm{~m}$ at VES No. 31 to 110 $m$ at VES No. 26.

e- The geoelectrical layer (D5) is observed at a southern part of the study area which represents a small distribution in the study area. This layer displays relatively low resistivity values varies from 2.8 to $9.8 \Omega$.m corresponds to shale. The thickness of this layer varies from $10 \mathrm{~m}$ at VES No. 33 to $33 \mathrm{~m}$ at VES No. 43.

\section{- The Fifth Geoelectrical Unit (E):}

This layer observed at central and southern parts of the study area which represents a wide distribution in the study area. This layer has resistivity values varies from 50 to $190 \Omega$.m corresponds to water-bearing limestone of Minia Formation, which represents the fourth and last aquifer in the study area.

-The lithological successions from surface to base are affected by a group of inferential normal faults that have direct effect on the shape of the surface terrain and groundwater occurrences, the cross section BB' has two normal faults F1 and $\mathrm{F} 2$ act as a graben form, the cross section $\mathrm{CC}$ ' has normal fault $\mathrm{F}$ 3, the cross section EE' has two normal faults F4 and F5 act as a graben form, the cross section GG' has two normal faults F6 and F7 act as a graben form, the cross section JJ' has two normal faults F8 and F9 act as a step form , and the longitudinal cross section KK' has a seven normal faults (F10, F11, F12, F13, F14, F15 and F16) act as a graben and horst forms.

\section{Hydrogeological Setting:}

According to the geoelectrical results, the investigated area is characterized by four waterbearing geoelectrical layers (A3, C1, D4 and E) which represent four groundwater aquifers from top to base are:

1. Quaternary Aquifer (A3).

2. Maghagha Aquifer (C1).

3. Samalut Aquifer (D4).

4. Minia Aquifer (E).

A description of each aquifer is given as the following:

\section{Quaternary Aquifer (A3):}

Based on the geoelectrical results, the water bearing Formation "layer A3" varies in resistivity from 2 to $10 \Omega$.m corresponds to water bearing neonile deposits (Pleistocene) which composed of sands and gravels with clay and shale lenses. This geoelectrical layer (A3) is observed at northern and west southern parts of the study area at VES's No. 7 and 37 which represents a small distribution near the Nile River in the study area )Fig. 17).

\section{Maghagha Aquifer (C1):}

According to the geoelectrical results, the water bearing Formation "layer C1" varies in resistivity from 75 to $136 \Omega$.m )Fig. 18) corresponds water-bearing limestone of Maghagha Formation. This layer observed at the extremely northern part of the study area at VES's No. 1 to 6 which cover a small part of the study area. The Isopach map ) Fig. 19) indicates that the thickness values of this layer range between 15 and $50 \mathrm{~m}$

\section{Samalut Aquifer (D4):}

According to the geoelectrical results, the water bearing Formation "layer D4" varies in resistivity value from 30 to $200 \Omega$.m corresponds to water-bearing limestone of Samalut Formation. The Iso-resistivity contour map )Fig. 20) of the water-bearing Formation "layer D4" indicates that the resistivity decreases towards the central part at Wadi El Sharawna area. The Isopach map )Fig. 21) indicates that the thickness of layer "D4" varies from 19 to $110 \mathrm{~m}$ This layer represents a wide distribution started from wadi El Sharawna at VES No. 12 to wadi El Sheikh Hasan at VES No. 31, the maximum thickness of this layer reported at El Salam new village at VES No. 26.

\section{Minia Aquifer (E):}

According to the geoelectrical results, the water bearing Formation "layer E" varies in resistivity from 50 to $190 \Omega$.m corresponds to water-bearing limestone of Minia Formation. The Iso-resistivity contour map )Fig. 22) of the water-bearing Formation "layer E" indicates that the resistivity increase towards the area between central and southern regions at Wadi El Sheikh 
Hasan area from VES No. 31 to VES No. 36.

\section{Depth of Water Bearing Formation Contour Map:}

The depth of water bearing Formation varies from $5 \mathrm{~m}$ to $110 \mathrm{~m}$ (Fig. 23), and it decreases towards the Nile river (to the west) and the maximum depth of water bearing Formation is noticed at Wadi El Sharawna area at VES's No. 12, 13, $14,15,45,46$ and 47 due to the presence of large continuous shale layer of Maghagha Formation, which covers the water-bearing limestone of Samalut Formation (the third aquifer), hence, this aquifer consider confined aquifer in the Wadi El Sharawna area.

\section{Water Bearing Formations Extension (Panel Diagram):}

Panel diagram bounded the study area has been constructed to demonstrate the 3D variation in the geoelectrical layer of the study area) Fig. 23), we will concentrate on the extension of the water-bearing Formations.

Firstly, we note the presence of Maghagha aquifer in the northern region, it is represented by water-bearing limestone layer which cover a small part in the extremely north of the study area and separated from the diagram by the presence of two faults because of the abrupt change in the geoelectrical resistivity values.

Secondly, if we turn south, we note the emergence of Samalut aquifer, it is represented by water-bearing limestone layer which occupy a large part in the study area, started from Wadi Awlad El Sheikh at the north at VES's No. 8 and 11 to Wadi El Sheikh Hasan at the south at VES's No. 31 and 36. This layer is completely faded at Wadi Al Sariria at the extremely southern part. Also, we can see this layer covered by a continuous shale layer of Maghagha Formation from Wadi Awlad El Sheikh to the central part at VES's No. 12 and 21; hence, this aquifer is considered a confined aquifer type. In addition, the shale layer affected on the depth to Samalut aquifer.

Finally, Minia Aquifer is extended below the Samalut aquifer from the central part of the study area to the southern part where the Samalut aquifer is completely faded at Wadi Al Sariria at the extremely southern part. Also, we can see that, this layer covered by a continuous shale layer of Samalut Formation.

\section{Priority Map for Groundwater Exploitation of Samalut Aquifer (D4):}

Generally, a priority map has been generated for exploiting geoelectrical water-bearing layer D4 in the case of drilling deep wells. This map defines zones of different priorities for groundwater exploitation. There are not abrupt changes in the resistivities and thickness of this layer. Since, the depth to water play a significant role in groundwater utilization, consequently the weighting factors of the depth to water, resistivity and thickness of water-bearing layer are $60 \%$, $20 \%$ and $20 \%$ respectively. These factors are essential for the construction of such map. The resistivity, thickness and depth to water have been categorized into three categories as shown in table (2).

The groundwater priority map for Samalut aquifer D4 in the investigated area )Fig. 24) indicates that the most promising area for drilling well, located at the area between the central and Southern regions along the VES's No. 31 to 36 at wadi Awlad El Sheikh area. The second site for drilling is located at the central part and extend along the Nile river at VES's No. 8, 12, 16, 19, 20, 21 and 22 followed by VES's No. 25 to 30.

Finally, the third area for drilling is located at the area between the central and northern regions (Fig. 24).

\section{Priority Map for Groundwater Exploitation of El-Minia Aquifer (E):}

Generally, a priority map has been generated for exploiting geoelectrical water-bearing layer $E$ in the case of drilling deep wells. This map defines zones of different priorities for groundwater exploitation. The base of this water-bearing layer has not been recorded. Since, the resistivity and the depth to water play a significant role in groundwater utilization, consequently the weighting factors of the depth to water and resistivity of water-bearing layer are $70 \%$ and $30 \%$ respectively. These factors are essential for the construction of such map. The resistivity and depth to water have been categorized into three categories as shown in table (3). 
The groundwater priority map for El Minia aquifer $\mathrm{E}$ in the investigated area ) Fig. 25) indicates that the most promising area for drilling well tapping is located at the extremely Southern region where, wadi El Saririia area which located along VES's No. 38 to 44. The second site for drilling is located at the area between the central and Southern regions at VES's No. 16, 19, 20, 21 and 22 followed by VES's No. 25 to 36 .

Finally, the third area for drilling is located at the area between the central and northern regions at VES's No. 12 to 15 followed by VES's 17, 18, 22 and 23 )Fig. 26).

In the light of this study, it can be concluded that, the priority of groundwater occurrences and it's exploitations in the study area generally increases toward the southern parts, especially at wadi El Saririia area where El Minia Aquifer occupy the first category and at wadi El Sheikh Hasan where the two main aquifers of Samalut and El Minia facies are well represented.

\section{CONCLUSIONS}

Based on the obtained geophysical results, four water-bearing layers (aquifers) (A3, C1, D4 and $\mathrm{E}$ ) were detected in the investigated area. The Quaternary deposits represented by Pleistocene Neonile Sediments of sands and gravels with clay and Shale lenses (A3) act as the first aquifer which represents a limited distribution in the investigated area. The second water-bearing layer (C1) corresponds to water-bearing limestone of Maghagha Formation which lead to the second aquifer which represents a limited distribution in the investigated area. The third one (D4) corresponds to water-bearing limestone of Samalut Formation which lead to the third aquifer, which represents a wide distribution in the investigated area. The fourth one (E) corresponds to waterbearing limestone of Minia Formation which lead to the fourth aquifer and represents a wide distribution in the investigated area.

The depth of water-bearing Formations varies from $5 \mathrm{~m}$ to $110 \mathrm{~m}$ and it decreases towards the Nile river (to the west) and the maximum depth of water bearing Formation is noticed at Wadi
El Sharawna area due to the presence of large continuous shale layer of Maghagha Formation which covers the water-bearing limestone of Samalut Formation (the third aquifer), hence, this aquifer consider confined aquifer in the Wadi El Sharawna area.

According to the priority maps, it can be concluded that, the priority of groundwater occurrences and it's exploitations in the study area generally increases toward the southern parts especially, at wadi El Saririia area where El Minia Aquifer occupy the first category and at wadi El Sheikh Hasan where the two main aquifers of Samalut and El Minia facies are well represented.

\section{REFERENCES}

Attia, M I., (1954): "Deposits in the Nile Valley and the Delta.” Geol. Surv., Cairo, Egypt”.

Boukhary, MA.; Abdel Malik, W.M (1983): "Revision of the stratigraphy of the Eocene deposits in Egypt" N. Jb. Geol. Palaeont., Mh. 6:321-337.

EGSMA; NARSS; UNDP; UNESCO (2005): “Geological Map of Al Minya Quadrangle, Egypt" Scale 1:250 000, Sheet NH - 36 A.

IPI2win program (2003): "Resistivity Sounding Interpretation program Version 3.0.1.a 7.01.03(1990-2003)" Moscow State University. Moscow, Russia.

Omara, S.; Philobbos, E.R.; Hanna, S.S. (1973): “Contribution to the geomorphology of the east of Minia" Bull. Soc. Geor. Egypt, 45/46: 125/147.

Omara, S.; Mansour, H.H.; Youseef, MM; Khalifa, H. (1977): "Stratigraphy, paleoenvironment and structural features of the area east of Beni-Mazar, Upper Egypt" Bull. Fac. Sci., Assiut Univ. 6(3): 171.

Said, R. (1962): "The geology of Egypt.” Elsevier, Amsterdam Pub. Co., P. 377.

Said, R. (1981): "The Geological Evaluation of the River Nile." Springer - Verlag; New York, Inc. P. 151.

Said R. (1990): "The geology of Egypt." Consultant, annals, Virginia, USA and Cairo Egypt. P. 487-523.

Strougo, A.; Bignot, G.; Boukhary, M; Blondeau, A. (1990): "The upper Libyan (possibly Ypresian) carbonate platform in the Nile Valley, Egypt" Revue De Micropaleontogie, 33(1): 45-71.

Tamer, M, A.; El Shazly M; Shata, A. (1974): “Geology of El - Fayum, Beni - Suif Regions.” Bull. Desert Inst. Egypt, Vol. 25, No. 1, 2 P. 27-47.

Youssef, M I. (1968): "Structural Pattern of Egypt and its interpretation" Bull. Amer. Assoc. Petrol. Geol., Vol. 52, No. 4, P. $601-614$. 